\title{
O INTUICIONISMO MORAL E A ÉTICA DOS DESAFIOS
}

\section{RUITEMBERG NUNES PEREIRA*}

Comment les idées, qui marchent d'un pas si régulier et si ferme dans la cervelle sur un grand nombre d'objets, peuvent-elles clocher si misérablement sur un autre mille fois plus palpable et plus aisé à comprendre?

Cet homme a toujours en lui les memes principes d'intelligence; il faut donc qu'il y ait un organe vicié, comme il arrive quelquefois que le gourmet le plus fin peut avoir le goût dépravé sur une espèce particulière de nourriture.

VOLTAIRE

RESUMO: A filosofia moral de Dworkin pode ser considerada uma estratégia teórica para fundamentar a sua filosofia política. Nesta perspectiva, Dworkin adota um descritivismo moral de base intuicionista e uma ética dos desafios para desconstruir o ceticismo moral, que poderia constituir um obstáculo ao desenvolvimento das ideias da igualdade liberal. A pretensão de integrar filosofia moral e filosofia política, contudo, enseja paradoxos e dificuldades que precisam ser analisados e discutidos com espírito crítico.

PALAVRAS-CHAVE: Filosofia moral; Ronald Dworkin; Intuicionismo; Ética dos Desafios; Neutralidade; Liberalismo; Comunitarismo.

ABSTRACT: Dworkin's moral philosophy can be regarded as a theoretical strategy to support its political philosophy. In this perspective, Dworkin adopts a basic moral descriptivism intuitionistic and ethics of the challenges, in order to deconstruct the moral skepticism, which could represent an impediment to developing the ideas of liberal equality. The desire to integrate moral philosophy and political philosophy, however, give rise to paradoxes and difficulties that must be analyzed and discussed critically.

KEYWORDS: Moral philosophy; Ronald Dworkin; Intuitionism; Ethics of Challenge; Neutrality; Liberalism; Communitarianism.

SUMÁRIO: Introdução; 1. O Intuicionismo Moral de Dworkin; 2. A Ética dos Desafios; Conclusões; Referências Bibliográficas.

SUMMARY: Introduction; 1. The Dworkin's Moral Intuitionism; 2. The Ethics of Challenges; Conclusions; References.

\footnotetext{
Artigo recebido em 16.08.2010. Pareceres emitidos em 1․09.2010 e 22.09.2010.

Artigo aprovado para publicação em 29.09.2010.

* Doutorando em Direito das Relações Internacionais (FAJS/UNICEUB/DF). Mestre em Direito e Estado pela Universidade de Brasília (UnB/DF) e Juiz de Direito substituto do Tribunal de Justiça do Distrito Federal e dos Territórios.
} 


\section{INTRODUÇÃO}

A teoria jurídica desenvolvida por Ronald Dworkin é profundamente permeada de filosofia moral e política, embora em sua ampla produção acadêmica destaquem-se poucos títulos dedicados especificamente aos temas da ética e da moralidade. Construções teóricas como a crítica ao positivismo jurídico, o modelo teórico da integridade moral do Direito, a defesa dos juízes como atores políticos e a tese filosófica dos desafios da igualdade liberal demonstram a preocupação dworkiniana de desenvolver as bases éticas de sua teoria política.

A análise da filosofia moral de Dworkin, desse modo, ajuda-nos a compreender melhor a estrutura do seu pensamento nos âmbitos do Direito e da Política, no contexto dos quais tomam lugar questões importantes como a relação entre a justiça e a virtude, a possibilidade de uma objetividade e de uma transitividade no campo da filosofia moral, especialmente no cenário das controvérsias ou dilemas morais, o significado do indivíduo no contexto de sua comunidade política, a tensão entre igualdade e liberdade, o papel do judiciário nos tempos atuais dentre outras.

No âmbito da filosofia política, as afinidades ético-morais aristotélicas confrontam-se com a autodeterminação do individualismo próprio do pensamento liberal à moda americana, que se propõe a mitigar o projeto coletivo do pensamento de Aristóteles, reconstruindo uma ética indexada pela transcendente cultura comunitária sem perder de vista a liberdade de autodeterminação e de escolha do indivíduo no tocante à sua forma particular de vida boa. Como Dworkin pretende conciliar esse individualismo que prega uma liberdade como autoconstrução do agir ético com o papel da comunidade política que é tão expressivo nas éticas de inspiração aristotélica? Como o autor desenvolve a problemática busca de uma conciliação do universal da justiça comunitária com o particular das virtudes que sustentam a ética privada autodeterminada?

No campo da filosofia moral, Dworkin parece defender um intuicionismo de bases realistas, representado na tese da existência de uma face-value das moralidades substantivas que constitui o elemento de interligação entre essas moralidades no contexto de diversidade ou de pluralismo cultural. Essa ideia de uma integridade da razão prática, contudo, não parece infensa às críticas que são correlatas ao seu próprio intuicionismo ético. Como conciliar o cognitivismo da objetividade das conviç̧ões morais substantivas com a noção imperativa do pluralismo moral?

O objetivo desta pesquisa é basicamente o de analisar o diálogo das premissas teóricas da filosofia moral e da filosofia política de Dworkin, enfatizando o intuicionismo ético e a crítica dworkiniana ao ceticismo moral, e o modelo ético dos desafios, a partir do qual Dworkin pretende reconciliar justiça e virtude e assim fundar as bases de seu liberalismo igualitário. Assim pretende-se desenvolver a hipótese de que as percepções teóricas de Dworkin no campo da política refletem basicamente as suas intuições no campo da teoria moral, não havendo como dissociá-las. A pesquisa pretende contribuir para a perspectiva de que as teses morais de Dworkin culminam na justificativa moral do seu liberalismo. 


\section{O INTUICIONISMO MORAL DE DWORKIN}

Com o objetivo de situar o pensamento moral de Dworkin no contexto das teorias éticas ou da filosofia moral ${ }^{1}$, utilizaremos a taxonomia desenvolvida por Richard $\mathrm{M}$. Hare (2003), menos por sua pretensão de completude e exaustividade do que pela clareza de sua formulação. Hare chama de "teorias éticas" aquelas que estudam o "significado e as propriedades lógicas das palavras morais. Essas teorias poderiam ser agrupadas, segundo ele, em dois grandes gêneros, denominados de (1) descritivismo e (2) não-descritivismo.

Segundo Hare (2003:77-78), o descritivismo consiste na teoria moral segundo a qual o significado (sentido e referência) de um enunciado moral (ato de fala moral) esgota-se nas suas condições de verdade como enunciados descritivos (condições sob as quais seria correto dizer que ele é verdadeiro). Ao contrário, o não-descritivismo moral - ao qual Hare se declara filiado, uma vez que não acredita em morais substantivas (do que se destaca a oposição de Dworkin), mas apenas na logicidade da linguagem moral vista sob um enfoque prescritivista universal ou formal, em certo sentido sustenta que tais condições de verdade dos atos de fala morais podem ter um papel importante para o seu significado, mas não o esgotam completamente, porquanto tal significado também compreende um elemento avaliatório (valorativo). Nesse sentido, se para os descritivistas, modificando-se as condições de verdade dos enunciados morais, modifica-se igualmente o significado desses enunciados, para os não-descritivistas, é possível que o significado permaneça o mesmo, ainda que alteradas as condições de verdade. Em outros termos, descritivistas e não-descritivistas divergem sobre 0 caráter necessário e suficiente das condições de verdade dos enunciados morais.

Consideremos o exemplo de uma comunidade moral em que é amplamente aceito o dever moral de os filhos menores observarem as recomendações e ordens de seus pais. Necessitando dirigir-se ao hospital para visitar a esposa que se acha ali internada, o pai recomenda à sua filha adolescente que permaneça em casa e dela não se ausente em hipótese alguma. A filha assim o faz. Contudo, repentinamente, inicia-se um incêndio na residência. O que ela deve fazer? Segundo os descritivistas, diante da ocorrência excepcional, o significado do enunciado moral constante do ato locucionário manifestado pelo pai alterou-se, uma vez que alteraram-se as condições de verdade subjacentes a este ato de fala, que pressupunha uma situação fática de normalidade. Por conseguinte, o significado dos atos de fala moral resume-se à adequada descrição racional das condições de verdade, que compreende o sentido e a referência dos atos de fala.

\footnotetext{
${ }^{1}$ Os termos filosofia moral e (meta)ética carregam o sentido da reflexão metaética sobre a moralidade (moral), que por sua vez indica os conteúdos dos princípios que norteiam a ação humana. A filosofia moral é a disciplina que encerra os conceitos e argumentos para a ética como reflexão e como um "corpo de saber". Desse modo, aqueles termos alinham-se mais com a idéia formal ou metodológica do juízo crítico sobre os modelos teóricos que pensam o como agir e como se constrói a racionalidade da conduta humana. Nesse sentido, as distinções de Neri (2004) e Canto-Sperber (2005). Contudo, Dworkin confere sentido completamente diferentes para esses termos, como veremos, pois define a ética como a liberdade do indivíduo para escolher os seus desafios e projetos de vida pessoal, reservando o termo "moral” para a definição do modo como devemos agir em relação aos outros. Assim, ética tem um sentido subjetivo e particular; moral, um sentido objetivo e universal.
} 
Assim, apesar de o sentido perlocutório do ato de fala manifestado pelo pai recomendar a consequência prática da obediência por parte da filha, e considerando-se que as condições de verdade, alterando-se, modificaram tal significado, os descritivistas concluiriam que a "desobediência" da filha, ao abandonar a residência e assim salvar a sua vida, não constituiria uma prática moralmente reprovável. Os não-descritivistas concordam, evidentemente, com a conclusão, mas discordam das premissas. Não se trata, no caso, de uma transformação valorativa do enunciado moral, que não passa desta forma da categoria dos recomendáveis para a dos não-reprováveis. O sentido valorativo ou a força ilocucionária da máxima de que os filhos devem atender às recomendações de seus pais permanece o mesmo, ainda que as condições de verdade do caso se tenham modificado.

Segundo Hare, apesar da proximidade conceitual, as premissas teóricas do descritivismo e do não-descritivismo não podem ser confundidas com as dos pares realismo/anti-realismo e cognitivismo/não-cognitivismo no campo da filosofia moral. ${ }^{2}$ Para Hare a diferença específica entre descritivistas e não-descritivistas reside na função dos juízos valorativos. "O descritivista acha que, se as condições de verdade de um enunciado moral tiverem mudado, seu significado, como um todo, deve ter mudado; um não-descritivista, contudo, sustenta que isso não é assim. Ele acha possível que um enunciado moral retenha o mesmo significado valorativo enquanto muda seu significado descritivo, suas condições de verdade e sua semântica. Isso porque há uma porção extra de input que entra na formação de um enunciado moral, que não está presente na formação de um enunciado ordinário puramente descritivo."3

Esse traço formal comum entre diferentes perspectivas descritivistas é que fundamentará a perspectiva de Hare de uma ética universal não-descritivista, não-ontológica ou formal, a partir da qual Hare pretende sustentar um verdadeiro diálogo entre tradições morais diversas, no âmbito das quais, a despeito da diversidade cultural, seria possível a identificação de um elemento lógico e formal identificador, capaz de afastar o sentido de contradição moral entre as culturas e fundamentar um sentido de consistência entre elas.

\footnotetext{
${ }^{2}$ Hare considera que a distinção entre cognitivistas e não-cognitivistas é enganosa e não retrata a distinção entre descritivistas e não-descritivistas, uma vez que tanto aqueles quanto esses não rejeitam a possibilidade de se "pensar racionalmente sobre questões morais" ou de se reconhecerem como "verdadeiros" certos enunciados morais, do que não se poderia extrair uma differentia específica, do mesmo modo que tal diferença não poderia derivar da distinção descrever/valorar, uma vez que as discordâncias entre sujeitos morais pode decorrer não da impossibilidade de acesso ao verdadeiro ético, como sustentam os não-cognitivistas, mas sim das discrepâncias dos nossos jogos de linguagem. Desse modo, a mínima tendência dos juízos morais à verdade e à prescritividade universal seria um elemento comum entre cognitivistas e não-cognitivistas, se consideradas todas as circunstâncias e possibilidades do conflito moral. Ao contrário, esse elemento comum não se encontraria nos círculos dos descritivistas e não-descritivistas, à medida que aqueles consideram que a modificação das condições de verdade do juízo moral implica necessariamente a mudança do próprio juízo moral, ao passo que esses, como Hare, consideram ser possível a permanência do significado veritativo do juízo moral a despeito das mudanças das condições de verdade, o que não se modifica com a modificação dos jogos de linguagem. Portanto, a distinção entre descritivistas e não-descritivistas é mais precisa, uma vez definida a diferença específica entre ambos.

${ }^{3}$ Hare, 2003:83.
} 
Hare subdivide as teorias descritivistas em duas espécies: (1.1) naturalismo (que se subdivide entre naturalistas objetivistas e naturalistas subjetivistas) e (1.2) intuicionismo. Do mesmo modo, subdivide as teorias não-descritivistas em duas categorias: (2.1) emotivismo e (2.2) não-descritivismo racionalístico (onde situa o prescritivismo universal). Os naturalistas são aqueles que acreditam que o ético tem uma relação causal com o que se denomina de "propriedades naturais" aplicáveis num sentido "padronizado”, cuja posse determinaria um juízo ético dotado de condições de verdade sem o apelo a qualquer termo ou propriedade moral. "As condições de verdade dos enunciados morais são determinadas pela correta aplicação de predicados morais como 'certo', 'errado', 'bom' e 'mau' para ações ou pessoas.” Os naturalistas objetivistas acreditam que tais propriedades naturais podem ser aplicadas como condições de verdade independentemente das ações concretas ou da sociedade/comunidade em que essas ocorrem. Os naturalistas subjetivistas, ao contrário, sustentam que isso não seria possível, pois as propriedades naturais dizem respeito inescapavelmente às atitudes das pessoas que proferem juízos morais.

Para Hare, o problema fundamental dos naturalistas reside no seu inevitável relativismo moral. Se os juízos morais decorrem das condições de verdade inseridas na cultura ou nas atitudes das pessoas, uma mesma conduta pode ser considerada, sob ângulos diversos, como certa ou errada, ainda que no contexto de uma mesma cultura (no caso dos dissidentes morais de uma sociedade plural, como as sociedades ocidentais em geral). Sob esse enfoque, seria lógico concluir que os juízos morais dos responsáveis pelos atentados de 11 de setembro, nos Estados Unidos, não conflitam verdadeiramente com os juízos morais das vítimas desses atentados ou dos demais cidadãos norte-americanos. As conviç̧ões morais de ambos os lados do conflito poderiam ser considerados moralmente certas, a seu modo e conforme a sua própria cultura.

Assim, os juízos morais, segundo os naturalistas, não passariam do aprendizado de um jogo de linguagem moral, a partir do qual as pessoas aprenderiam a bem empregar os sentidos dos conceitos morais construídos tradicionalmente. Desse modo, o fato de uma cultura considerar a eutanásia um ato moralmente "errado" e outra considerá-la "correta” significaria apenas que essas culturas estariam empregando os conceitos morais de "errado" e "correto" em jogos de linguagem diferentes, consideradas as propriedades naturais de que esses conceitos estariam imbuídos numa e noutra cultura. Essa conclusão decorre do necessário reconhecimento de que, pela própria diversidade inevitável das culturas, não se poderiam identificar propriedades naturais de uma moralidade substantiva universal.

Os naturalistas estariam a confundir a distinção entre descrever propriedades naturais e valorá-las conforme princípios morais substantivos, descurando do próprio fato de que mesmo algumas palavras de feição descritiva podem ser empregadas com forte sentido valorativo. Quando me dirijo a alguém e digo: "Você engordou!” ou “os seus cabelos estão ficando brancos!”, por mais explicações que eu possa dar ao meu interlocutor no sentido de que me limito a narrar um fato, é impossível afastar a carga valorativa que os meus atos de fala ostentam e que vão além das meras considerações estéticas, alcançando até mesmo o grau de juízos morais substantivos (em favor de 
certos hábitos de vida ou de determinados estados mentais). Assim, a distinção entre fato e valor e a própria falácia naturalista merecem ser rediscutidas. O próprio relativismo - como Hare reconheceu - é uma teoria moral substantiva. Ele "diz que qualquer coisa que alguém diga que é errado é errado, e o mesmo vale para “certo'”.

Se duas culturas diversas têm visões diferentes sobre os conceitos de "gordo" ou "velho" ou mesmo atitudes diferentes em relação a pessoas com sobrepeso ou em idade avançada, tais distinções não podem ser atribuídas apenas à diversidade sobre os jogos de linguagem que essas culturas adotam com aqueles conceitos, mas verdadeiras atitudes morais substantivas em relação aos indivíduos com tais e quais características físicas ou psíquicas. Ainda que haja conceitos imbuídos de uma forte carga valorativa, o estudo dos juízos morais não se pode resumir à simples descrição de propriedades naturais ou à formação de um apanhado coerente de informações e de conhecimento. O naturalismo cai no paradoxo do certo/errado simultâneo: os juízos morais são certos e errados, conforme o ponto de vista do observador ou do participante.

O cognitivismo dworkiniano decorre de sua aceitação do que denomina de "face-value", a partir da qual sustenta que há respostas corretas (verdadeiras) no contexto de dilemas morais, no sentido não de uma única resposta correta, mas no sentido de que é possível racionalmente afirmar determinados juízos morais como certos ou errados. O certo e o errado do ponto de vista moral podem ser afirmados racionalmente, com o que Dworkin se afasta de um não-cognitivismo, de um ceticismo moral geral e portanto das formas conhecidas de naturalismo. ${ }^{4}$

Dworkin distingue dois tipos de ceticismo moral. ${ }^{5} \mathrm{O}$ primeiro, que assume uma forma externa, geral e abrangente, sustenta que não há verdades morais tout court, all the way down, o que Dworkin denomina de arquimedianismo (archimedianism); o segundo, que ostenta caráter mais limitado, seletivo ou descritivo, diz que somente são possíveis verdades morais em relação a juízos descritivos (destacadamente os conceitos aplicados pelas ciências duras, como a matemática e a física), mas não em relação aos juízos avaliatórios (morais, éticos, interpretativos ou estéticos). A segunda modalidade de ceticismo moral corresponde ao que Dworkin denomina de emotivismo.

A crítica central de Dworkin reside na tese de que as teorias céticas não são bem-sucedidas, sobretudo quanto ao propósito de desconstruir os conceitos de neutralidade e austeridade aplicáveis aos dilemas morais, porquanto tal propósito revela por si mesmo uma teoria moral substantiva, o que conduz os céticos a uma auto-contradição, à medida que não seria possível ser completamente cético do princípio ao fim (all the way down). Neste ponto, Dworkin explora, ainda que sem citá-lo expressamente, uma abordagem que pode ser identificada na tese da tirania dos valores de Carl Schmitt, segundo a qual a (des)valorização dos valores é ela própria um valor, ou seja, a própria neutralidade a valores é um valor em si, de modo

${ }^{4}$ Sobre a relação entre naturalismo, cognitivismo e realismo moral, v. Pigden (1993:421).

5 Dworkin define "ceticismo" como a rejeição de certas opiniões filosóficas sobre a moralidade, não a rejeição da moralidade em si ou outras formas de agnosticismo. 
que constitui uma questão hermenêutica a própria interpretação de quão cética, neutral, objetiva, descritiva ou racional uma teoria moral seja. ${ }^{6}$

Mesmo o relativismo, ao qual Dworkin faz referências críticas ao citar os exemplos da moralidade no cenário das relações internacionais ou do multiculturalismo, assume-se como um juízo moral positivo, que, longe de comprovar a neutralidade axiológica, avança a ideia de uma crítica substantiva à ideologia dos valores (imperialismo econômico, militar ou político, notadamente no campo dos direitos humanos), fundada na perspectiva de uma rejeição de valores universais ou universalmente prescritíveis, em prol da defesa de valores locais (particulares) desenvolvidos pelas diferenças culturais nacionais. Na base dessas ideias está a conclusão de que mesmo os juízos morais descritivos adotam avaliações contrafactuais positivas (counterfactual ascriptions).

A crítica de Dworkin se expande por ocasião da discussão dos dois fundamentos principais das correntes céticas: a neutralidade e a austeridade. A austeridade é o atributo da teoria cética segundo a qual os juízos morais não se baseiam em fundamentos primeiros, gerais, contrafactuais ou em julgamentos morais teóricos positivos (substantivos), mas sim em argumentos não-morais ou factuais (non-moral arguments). A neutralidade, por sua vez, adota uma postura epistemológica moral à humptydumpty $^{7}$, pois não toma partido em matéria de controvérsias morais e defende apenas juízos sobre juízos morais (second-order opinions). Neste sentido, a neutralidade não ostenta um ceticismo sobre as moralidades substantivas, mas sim sobre a possibilidade do reconhecimento de uma face valorativa (face-value) dessas moralidades substantivas. A partir desses atributos, não seria dado ao arquimedianismo reconhecer o nazismo, o genocídio, a tortura de crianças, o terrorismo, o tráfico de pessoas, a escravidão como condutas imorais.

Do ponto de vista da neutralidade, tais ações constituem apenas fatos, aos quais se adscrevem valores conforme as convicções morais as mais diversas, o que se poderia comprovar pela persistência de algumas dessas práticas ainda na atualidade. Do ponto de vista da austeridade, o caráter moralmente certo ou errado dessas ações deriva de fatores não-morais, sobretudo utilitaristas ou consequencialistas.

\footnotetext{
${ }^{6}$ Schmitt (2009, 58-60): “Tramite la loro affermazione del carattere oggettivo dei valori da essi stessi posti, i nuovi valori non hanno fatto altro che introdurre - senza accrescere minimamente la loro evidenza oggettiva per chi la pensa in modo diverso - un nuovo elemento di autodifesa nel conflitto delle valutazioni, un nuovo aggregio dell'arroganza che può solo fomentare e inasprire la lotta. Per superare la teoria soggettiva dei valori e per garantire l'oggettività dei valori non basta occultare i soggetti e far tacere i portatori di valore, i cui interessi forniscono i punti di osservazione, i punti di vista e i punti di attacco del valutare. Nessuno può valutare senza svalutare, rivalutare e valorizzare. Chi pone i valori si è in tal modo già contrapposto ai non-valori. Non appena l'imporre e il far valere diventano davvero una cosa seria, la tolleranza e la neutralità illimitate dei punti di vista e dei punti di osservazione intercambiabili a piacere si ribaltano subito nel loro opposto, cioè in ostilità. L'anelito del valore alla validità è irresistibile, e il conflitto tra valutatori, svalutatori, rivalutatori e valorizzatori è inevitabile. (...) Anche l'avalutatività assoluta della scienza, infatti, può essere posta e fatta valere como valore, anzi addirittura come valore supremo, e nessuna coerente logica del valore può impedire, a chi ha posto e attuato questo valore supremo, di condannare como antiscientifica, antiprogressista e nichilistica l'intera filosofia dei valori. Il conflitto tra valutatori finisce così: da entrambe le parti risuona un orribile pereat mundus.”

${ }^{7}$ Referência à personagem de Lewis Carrol, que aparece em "Alice through the looking-glass”, procurando compor a instabilidade que lhe confere a sua compleição oval com o equilibrar-se "em cima do muro".
} 
A tortura, o genocídio, a escravidão poderiam ser reconhecidas como moralmente inaceitáveis não por causa de alguma máxima de dever a priori, mas sim por razões pragmáticas não-morais, como, por exemplo, o fato de que tais ações produzem a dor ou o sofrimento, o que contraria os ideais individuais de vida boa ou de felicidade em sentido amplo.

O utilitarismo moral (do qual o consequencialismo é uma versão) constitui a empreitada teórica mais bem sucedida (embora criticável) na busca por uma alternativa ao deontologismo universalista próprio das matrizes éticas kantianas. Com o utilitarismo moral (em suas diversas acepções) constrói-se a ideia de que seria possível identificar o moralmente correto independentemente de uma face-value ou de juízos avaliatórios acerca dos dilemas morais, à medida que o moralmente correto estar-se-ia assentado na pretensão de maximização objetiva de um bem ou de uma manifestação de poder individual ou coletivo.

Contudo, a par da circunstância de que um utilitarismo puro é inadequado, à medida que há razões morais outras a serem defendidas além da maximização da felicidade, tal corrente não pode significar o triunfo de uma filosofia moral ascética, neutra, austera, objetiva e impessoal, totalmente espargida de juízos avaliatórios e plenamente comprometida com os juízos descritivos. Não é tremulando a bandeira do utilitarismo que os céticos poderão festejar a vitória sobre particularistas, cognitivistas e não-descritivistas.

Os céticos parecem incomodados com o fato de que juízos morais fundados em proposições-E (“achamos que isso é objetivamente imoral”) servem apenas para ocultar juízos morais substantivos baseados em proposições-I ("nós achamos que isso é imoral”). A crítica de Hare aos descritivistas também identifica este ponto, ao assinalar que os juízos morais não se limitam à pura descrição de estados ou ações, mas sempre contém também juízos avaliatórios que incrementam um elemento novo nos julgamentos morais, o que afasta a neutralidade desses julgamentos, à medida que importa numa tomada de decisão moral substantiva. No mesmo sentido, para Dworkin (1996:127), "even the deepest skepticism is an opinion about what morality demands, and no argument can be decisive of that question that does not include premises or assumptions about what morality is for."

A "imoralidade" daquelas ações poderia ser admitida como reflexos da contingência e da circunstancialidade, e não uma questão de princípios abrangentes. Não haveria assim razões morais "out there" capazes de identificar esta ou aquela conduta como moralmente repugnante. $\mathrm{O}$ que existem são proposições externas não-morais, universais, objetivas e absolutas, que justificam racionalmente a ação humana (o que Dworkin denomina de further claims ou Proposições-E (de "Proposições Externas”), que nada mais são do que as propriedades morais dos naturalistas). ${ }^{8}$

${ }^{8}$ Ao tratar das "further claims”, Dworkin constrói uma interessante expressão (“morons”), que constitui um acrônimo das palavras "moral” e "íons" (mor + ons), para significar o que denomina de "partículas morais". Segundo os arquimedianos, existiriam na tessitura do universo e que permitiriam reconhecer a retidão ou irregularidade moral de uma ação humana independentemente de juízos avaliatórios. Assim como as partículas atômicas (prótons e nêutrons), haveria no universo partículas morais, por meio das quais qualquer ser racional poderia identificar o certo e o errado no âmbito dos dilemas morais. Dworkin denomina esta 
Esse naturalismo moral permitiria assim concluir que o aborto, por exemplo, seria moralmente errado com base em razões não-morais existentes independentemente de qualquer observador, cultura ou sociedade. Sob esse enfoque, portanto, a ideia de uma "face-value" das convicções morais substantivas constituiria uma ilusão, fruto de uma má-filosofia. Interessa notar que, como assinala Dworkin, as notas da neutralidade e da austeridade são parceiras de um mesmo projeto cético-moral. Ambas se complementam logicamente. É o anti-fundacionalismo que me permite ser um humpty-dumpty em questões morais. É a impossibilidade racional do tomar-partido que me faz rejeitar os fundamentos morais.

Dworkin destaca que alguns autores, como John Mackie, podem aceitar a austeridade, mas rejeitar a neutralidade, em face da diversidade moral (1996:113). Para Dworkin, contudo, o pluralismo moral não justifica o ceticismo, diante do reconhecimento da "face-value" como parte intrínseca da moralidade ordinária, a partir da qual é possível adotar uma estratégia adscritiva de sentido (certo/errado) às nossas crenças morais de tal modo que seja dado a todo ser humano medianamente racional identificá-las como dotadas daquele sentido.

Para Dworkin (1996:117), "human beings have a special though sometimes fallible faculty of judgement that enables us to decide which moral claims to accept or reject, a capacity whose malfunctioning may sometimes result only in moral misjudgment with no spillover impairment of other cognitive activity.” Desse modo, a filosofia moral de Dworkin pressupõe um sujeito moral, que estaria em cada um de nós, seres humanos racionais dotados de uma capacidade cognitiva para aceitar ou rejeitar asserções morais, capacidade típica da reconhecida e pressuposta pelos intuicionistas morais. $^{9}$

Dworkin não admite a possibilidade de que algum sujeito moral racional seja

tese de "moral-field thesis" e a qualifica como falsa, sustentando, basicamente, que tal falsidade reside na circunstância de que as pessoas teriam reações diferentes às denominadas partículas morais, de forma que não seria esse impacto que qualificaria determinada ação como moral ou imoral. Em outros termos, a mera catalese moral provocada pelas partículas morais não determinariam a ação humana, assim como o acúmulo de informações sobre o agir não determinam o próprio agir, o que é bem conhecido em diversas formas de ação humana, como o uso de drogas, o cometimento de delitos etc. Há outros fatores que pesam na causalidade da ação mais do que o conhecimento sobre o moral e o imoral ou mesmo sobre as conseqüências do agir, de forma que nem um nem outras podem invocar o monopólio das causalidades do agir. Outrossim, a levar radicalmente a sério a catalese dos morons o único resultado certo seria a ampliação do relativismo moral. Segundo Dworkin, “...the interpretive claim fails, not only because the moral-field thesis is absurd, but because no one thinks that the further claims do the justifying work they would, so interpreted, be meant to do. We should also notice, finally, that even if were sensible to attribute the moral-field thesis to the further claims, that would not convert them into neutral E-propositions, since we should then have to understand them as endorsing the view that the moral wrongness of genocide consists in the field that surrounds its instances, and that view is itself a (preposterous) substantive moral claim." (1996:105). Uma tese semelhante à do "moral-field" criticada por Dworkin poderia ser identificada no naturalismo de Fukuyama (2003), para quem o imperativo do respeito à dignidade da pessoa humana poderia assentar-se no simples conhecimento do "Fator X" como conseqüência da revolução da biotecnologia (o DNA da raça humana). "O fator X é a essência humana, o significado mais básico do que é ser humano. Se todos os seres humanos são, de fato, iguais em dignidade, $\mathrm{X}$ deve ser alguma característica universalmente possuída por eles.”

${ }^{9}$ Rawls, 1997:42.

DIREITOS FUNDAMENTAIS E E JUSTIÇA N' 12 - JUL./SET. 2010 
capaz de recusar-se a reconhecer como certo ou errado condutas como o terrorismo aplicado a crianças, o genocídio, a tortura por mero deleite pessoal. Há nessas condutas algo de profundamente errado, do ponto de vista moral, e esse "ser profundamente errado" configura a face axiológica da conduta que pode ser realisticamente identificada pela razão prática humana de um sujeito moral.

Sob esse enfoque, à medida que toda moralidade seria, segundo Dworkin, uma moralidade substantiva, também o seria a "face-value”, de forma que, nesse sentido, Dworkin distancia-se dos naturalistas objetivistas ou subjetivistas, pois não acredita ser possível formular juízos morais sobre o certo e o errado pela mera descritividade de propriedades não morais. Considerando que a "face-value" é o reflexo ponderado de uma moralidade substantiva reconhecível por sujeitos morais que compartilham a razão prática, Dworkin acredita que a moralidade seja uma dimensão onipresente, distinta e independente de nossa experiência, de cuja soberania nós não podemos fugir, a não ser se excluirmos a própria moralidade de nossas tradições.

Dessa forma, quando diferentes convicções morais entram em conflito é preciso restaurar a harmonia e a integridade quebradas, por meio intermédio de um procedimento prático-racional que considere todas as variáveis presentes na situação de conflito moral e que seja capaz de ponderar os valores em conflito de forma racional e aceitável, por intuição, sem que se especifique um método ético para o estabelecimento dos valores prioritários. Assim como não é dado aos homens saltarem para fora do universo da razão, do mesmo modo não é possível fugir da moral, haja vista que o fugir da moral significaria apenas a substituição de uma moral substantiva por outra.

Por conseguinte, sustentando a face-value e a moralidade como um domínio independente da nossa experiência, é forçoso reconhecer que Dworkin rejeita todas as formas de naturalismo, à medida que somente juízos morais poderiam qualificar juízos morais, não sendo possível que propriedades não-morais possam determinar a verdade de juízos morais. Nessa ideia está presente um intuicionismo moral e portanto uma crítica ao naturalismo, por se acreditar que a interligação das razões factuais envolvidas nos conflitos morais é algo diverso das atitudes e das ações humanas envolvidas (as questões de fato morais). ${ }^{10}$

Essa interligação lógica, pautada no raciocínio prático e numa ética da ponderação, transforma os elementos naturais (não morais) ou a base natural do juízo moral em elementos morais dotados de uma valoração moral. Dworkin não acredita numa dicotomia rígida entre fato e valor, de forma que a tese da falácia naturalista para ele não tem sentido, porquanto é impossível separarem-se elementos morais e não morais. Assim, a crítica de Dworkin à neutralidade em matéria de valores é também uma crítica ao naturalismo moral, à medida que a própria ideia de

\footnotetext{
${ }^{10}$ Dancy (1993:36) destaca essa oposição entre intuicionismo e naturalismo: "But the intuitionists rejected naturalism. They did this because of their pluralism. If one thinks that there are lots of different sorts of things that matter to how one should behave, in no very clear order or shape, one is going to think that there are too many different ways in which actions can be right or wrong. Rightness cannot be identified with any one of that there is no natural similarity between them all - the only common feature is the moral one, that each is a way in which an action gets to be right. The natural base for moral facts has no natural shape, and hence there is no common natural feature present for us to identify rightness with.”
} 
neutralidade fundada na defesa dos elementos não morais como a própria moralidade constitui uma moralidade substantiva.

Daí por que o pluralismo de convicções morais não se revela preocupante para Dworkin, uma vez que acredita existir um elemento comum na diversidade de convicções morais capaz de promover-lhes a interligação (como "struts of a geodesic dome”) e que esse elemento comum é precisamente a moralidade. A questão da neutralidade entra em cena devido ao fato de que a reflexão ética exigiria uma distinção intransponível entre os conteúdos morais e o exercício da razão prática.

Dworkin impugna essa percepção defendendo a ideia de que a própria ideia de neutralidade não preenche o pressuposto da neutralidade, pois já carrega consigo uma definição substantiva de vida boa. Desse modo, Objectivity and Truth é um trabalho esclarecedor sobre a ideia de integridade que vai nortear principiologicamente toda a obra de Dworkin e estabelecer o elo com a teleologia ética aristotélica. Explica-se portanto porque Dworkin transformou o princípio formal da integridade (integridade) no argumento central de sua filosofia moral, inclusive no campo do Direito.

A natureza, as ações e as atitudes humanas conteriam propriedades morais cujo entrelaçamento lógico reconhecível pelos sujeitos morais permitiria identificá-las como certas ou erradas, com fundamento nas crenças (beliefs), nos hábitos e nas convicções assentadas nas tradições. "In the beginning, and in the end, is the conviction". Não obstante, a filosofia moral de Dworkin não parece oferecer boas respostas para o problema do relativismo moral, se considerarmos, como na ironia de Descartes, que o bom senso moral de sujeitos morais é uma das qualidades mais bem distribuídas do mundo, ninguém dela se julgando mal aquinhoado. Dworkin também não nos oferece respostas sobre como as convicções morais se formam, uma vez que ele rejeita a causalidade das partículas morais (morons) e a tese do campo moral (moral-field).

É interessante destacar que Dworkin aceita a epistemologia interna do equilíbrio reflexivo com que Rawls desenvolveu o seu construtivismo moral kantiano, segundo o qual as nossas crenças morais estão interligadas em sentido lógico, sem vínculos causais diretos, formando um todo dotado de sentido, uma unidade de razão, perceptível pela capacidade humana reflexiva, mesmo na seara dos valores morais, adequada para a ponderação correta de princípios morais em conflito. "In the end the whole intellectual structure stands or falls together like the struts of a geodesic dome." Seguindo Kant, teríamos uma "totalidade sistemática dos fins de um reino dos fins (...) união dos princípios da razão prática com essas concepções que configuram a forma e a estrutura do procedimento." ${ }^{11}$ Sendo assim, o que Dworkin denomina de "face-value" constitui uma vertente da doutrina do fato da razão kantiana e configura o elo do pensamento moral de Dworkin com a racionalidade prática kantiana.

Como assinalado, o intuicionismo constitui a segunda espécie das teorias éticas descritivas, segundo a taxonomia de Hare. Rawls (1997:36-37) define o intuicionismo como “a doutrina segundo a qual há um conjunto irredutível de princípios básicos

${ }^{11}$ Rawls (2005:277).

DiReitos Fundamentais $\mathcal{E}$ J JustiçA N' 12 - JUL./Set. 2010 
que devemos pesar e comparar perguntando-nos qual equilíbrio, em nosso entendimento mais refletido, é o mais justo.” Para Rawls (1997:37), o intuicionismo sustenta duas premissas básicas: a) o pluralismo de princípios básicos que podem chocar-se e apontar diretrizes contrárias em certos casos; b) imprevisão de qualquer método específico ou regra de prioridade para avaliar esses princípios e compará-los entre si, que se julga desnecessário diante do equilíbrio alcançável pela intuição do que se nos apresenta como o mais justo. Segundo Dancy (1993:411), entre 1860 e 1920, o termo "intuicionismo" era apenas outro nome para "pluralismo", que por sua vez contrastava com "utilitarismo".

A proximidade da filosofia moral de Dworkin com o intuicionismo decorre da tese de que a verdade dos juízos morais consiste na "posse de propriedades especificamente morais, sui generis, que não podem ser definidas sem introduzir algum termo moral no definiens", 12 ao contrário do naturalismo, que sustenta que tal verdade se assenta na posse de propriedades não morais. De um modo geral, os intuicionistas acreditam ser possível afirmar que determinadas crenças morais ou enunciados morais são certos ou errados e que tal possibilidade se efetiva a partir de uma faculdade especial chamada intuição moral (moral intuition), uma vez que as razões morais que conduzem à formação das intuições entre sujeitos morais racionais são auto-evidentes (self-evidents). "Os intuicionistas éticos admitem que os juízos morais, que incluem o termo 'bom', ou que determinam deveres, atribuem propriedades a atos, pessoas ou coisas e que, neste sentido, dizem algo que pode ser considerado verdadeiro ou falso." ${ }^{3}$ Desse modo, os intuicionistas são cognitivistas em questões morais, embora muitos intuicionistas admitam certa dose de falibilismo, como parece ser o caso de Dworkin. O intuicionismo de Dworkin está bem representado pelas seguintes passagens (1996:92):

That is the view you and I and most other people have. We think that genocide in Bosnia is wrong, immoral, wicked, odious. We also think that these opinions are true-we might be sufficiently confident, in this case at least, as to say that we know they are true-and that people who disagree are making a bad mistake. We think, moreover, that our opinions are not just subjective reactions to the idea of genocide, but opinions about its actual moral character. We think, in other words, that it is an objective matter-a matter of how things really are-that genocide is wrong.

\section{(...)}

On the other hand, it is startlingly counterintuitive to think there is nothing wrong with genocide or slavery or torturing a baby for fun. I would need very powerful, indeed unanswerable, reasons for accepting this, and I think most other people would as well.

É próprio dos intuicionistas a invocação desses casos paradigmáticos para justificar o senso comum de uma comunidade moral, em relação aos quais se verificam

\footnotetext{
${ }^{12}$ Hare (2003:119).

${ }^{13}$ Vázquez (2002:245).
} 
consensos generalizados entre pessoas moralmente educadas e em relação aos quais, no plano conceitual, não há controvérsias sensíveis. Nisto reside o atrativo da teoria intuicionista. O problema de intuicionistas como Dworkin é que eles não dão maiores pistas acerca de uma teoria da argumentação racional que nos auxilie na construção lógica dos enunciados e da verdade moral subjacente aos consensos tradicionais que justificam o seu reconhecimento intuitivo.

Falta nos intuicionistas (e em Dworkin não é diferente) o desenvolvimento de uma epistemologia argumentativa que seja capaz de avançar para além dos limites do intuicionismo do sujeito moral por excelência, o juiz Hércules moral. Essa questão se revela problemática em Dworkin, à medida que este rejeita a ideia dos universais categóricos de dever, em prol da prevalência de uma igualdade liberal integradora da justiça e da virtude, mas não se desvencilha do mundo da inteligência moral em que se acha assentado o sujeito moral por excelência. Essa combinação de uma metafísica externa (fundada na noção abstrata do sujeito moral que não corresponde aos sujeitos reais inseridos nas tradições morais substantivas) com um realismo interno pertinente à face-value pode, no caso de Dworkin, transformar nobres sonhos em autênticos pesadelos.

Os intuicionistas sustentam que a verdade de nossas convicções morais não está pautada nas intuições individuais, mas em consensos generalizados entre sujeitos racionais que analisem e julguem os conflitos morais. No caso de Dworkin esses consensos generalizados estão representados na comunidade moral antropomorficamente pensada como sujeito moral por excelência, ao qual o indivíduo deve integrar-se e na qual este indivíduo encontra os parâmetros necessários para a definição dos seus próprios projetos morais particulares de vida boa. Neste cenário, novamente o relativismo moral nos ronda, porquanto os consensos morais generalizados guardam relação de pertinência com a diversidade das culturas. Desse modo, o intuicionismo moral não tem respostas adequadas para os casos que envolvem controvérsias morais profundas, como as práticas "homicidas” desenvolvidas por algumas culturas indígenas, a clitoridectomia, a pena de morte, a eutanásia, o abortamento dos anencéfalos etc.

O intuicionismo é importante apenas para nos dizer o que já sabemos a partir das nossas intuições generalizadas e da nossa própria noção de senso comum (comunitário). Ele nos diria, por exemplo, que é moralmente errado um grupo de jovens inescrupulosamente lançarem gasolina e atearem fogo em um mendigo que dorme ao relento. E daí concluiria, por intuição indutiva, que queimar seres humanos é moralmente repugnante, o que de fato não suscita quaisquer divergências, à medida que destruir vidas de corpos humanos é moralmente repugnante em que qualquer comunidade moral dotada de senso moral comum.

O problema que daí decorre está na pretensão megalomaníaca de fazer avançar o senso comum de forma abrangente, para alcançar a moralidade comunitária em geral, no sentido de que seja auto-evidente para as intuições humanas a natureza certa ou errada de quaisquer juízos morais. Evidentemente, não se pode abstrair a importância da imaginação e da reflexão intuitiva na formulação de juízos morais, do mesmo modo que, em qualquer julgamento moral, é importante identificar os aspectos relevantes do caso e analisar como esses diferentes aspectos interagem entre si. 
Pode ser, contudo, que tais critérios sejam até necessários, mas seguramente não serão suficientes para a identificação da face valorativa dos fatos humanos e da natureza da moralidade.

Hare assinala que os juízos morais se desenvolvem em dois níveis diferentes: (1) o nível intuitivo, em que operam as intuições representadas nos deveres e princípios prima facie e onde se situam as análises morais mais básicas, realizadas por sujeitos morais dotados da mais singela capacidade de reflexão moral; e o (2) o nível crítico, onde se opera a reflexão moral mais elaborada e que diz respeito basicamente à procura das soluções dos dilemas morais. Desse modo, ao contrário de Dworkin, embora os princípios morais e as intuições sejam importantes no primeiro plano do raciocínio moral, não se pode afirmar que tudo seja uma questão de princípios, uma vez que esses têm pouco a dizer no segundo plano da reflexão moral.

Assim, mostra-se inadequado sustentar que o raciocínio moral possa resumir-se ao nível básico das intuições, à medida que essas auxiliam a formação de juízos morais apenas nos casos simples, ou seja, aqueles em que se não verificam conflitos de deveres ou conflitos morais. Dito de outro modo, é necessário um segundo nível de reflexão moral ao qual estão atrelados os casos controversos. Neste nível, as intuições nada têm a contribuir, uma vez que a reflexão que ali se desenvolve baseia-se na razão prática e não em intuições fundadas em consensos, mesmo porque inexistentes tais consensos nos casos conflituosos.

Seguindo a proposta de Hare (1978), é forçoso reconhecer que a invocação do modelo teórico do construtivismo moral por Dworkin, longe de afastar a irrogação de um intuicionismo moral à sua doutrina, confirma tal intuicionismo, pois o construtivismo moral também se assenta na ideia de que seria dado ao indivíduo comum (a quem Hare denomina de "prole", para representar o indivíduo simplório, dotado de poucos recursos de conhecimento para realizar reflexões morais críticas) promover os seus raciocínios morais cotidianos, mesmo nos casos problemáticos, a partir das intuições que teria metafisicamente um indivíduo moralmente educado (o arcanjo de Hare ou o sujeito do mundo das inteligências de Kant), com o que seria possível identificar como moralmente certa ou errada determinada ação humana. Desse modo, o homem simplório e inculto seria capaz de manter contato metafísico com o seu (arc)anjo da guarda e assim poderia guiar a sua vida moral com segurança, sem o risco de ver qualificada como moralmente repugnante a sua conduta. A falta do segundo momento do raciocínio moral, que consiste na interposição do nível crítico ou reflexivo, constitui o principal problema desta perspectiva.

Como dito, as intuições são importantes porque guiam a moralidade cotidiana. Seria extremamente penoso se os homens fossem obrigados a promover densa reflexão crítica sobre cada um dos seus atos. Desse modo, uma vida totalmente desprovida de princípios intuitivos importaria o fim da própria vida humana, à medida que impediria o estabelecimento dos relacionamentos necessários à formação dos laços sociais. Um simples conversar com um estranho, um encontro num local público, um mover-se de um lugar a outro, o pronunciar uma palavra ficariam inviabilizados se a cada momento tivéssemos de refletir sobre o que é certo e errado. 
A humanidade não poderia sobreviver se a todo instante houvesse de formular essas indagações. Uma vida humana se mostra impossível sem essas pré-compreensões morais básicas, que se formam ao longo da vida a partir das tradições e das experiências que se vivem na comunidade. Dito de outro modo, a ausência de pré-conceitos morais configuraria a absoluta ignorância, que impede a política e a filosofia. ${ }^{14}$ Esses hábitos pelos quais formamos nossos princípios morais e que construímos a partir de nossas metáforas quotidianas são importantes elementos de controle da moralidade social substantiva.

O problema se coloca quando nos esquecemos que nossas intuições acerca de princípios morais são apenas metáforas e não verdades absolutas, e assim apagamos da nossa memória a contínua necessidade de desconstrução e reconstrução dos nossos valores (hábitos) morais. Para essa desconstrução e reconstrução as intuições morais nada tem a contribuir, exigindo-se uma filosofia moral capaz de nos fazer refletir sobre a natureza, da linguagem e da lógica da moralidade, nomeadamente no campo dos conflitos morais.

Nos casos morais controversos, não há consensos básicos generalizados, e os intuicionistas não nos apresentam elementos teóricos para identificar o certo e o errado no campo moral. Além disso, a própria ideia de consensos generalizados se revela complexa, sobretudo se considerarmos o contexto internacional da diversidade cultural humana e da possibilidade mesma de "conflito de intuições". O que para algumas culturas nacionais é uma luta louvável em favor de determinadas ideologias teológicas, para outras culturas (estrangeiras) pode constituir terrorismo ou corrupção moral. Neste aspecto não há intuição, faculdade moral ou consenso que sejam capazes de dizer quem tem a melhor razão moral, o que somente se pode definir a partir de um complexo raciocínio crítico inserido numa argumentação moral.

A simples evocação de consensos gerais nos contextos das tradições morais como critério para sustentar a racionalidade da adscrição do certo e do errado às ações humanas parece pouco realista, à medida que ignora o fato não apenas de que consensos podem significar tão-somente acordos estratégicos e não a verdade comunicativa,

\footnotetext{
${ }^{14}$ Intuições, pré-compreensões, pré-juízos e pré-conceitos integram a idéia de "senso comum” do homem e de sua comunidade moral. Assim estão relacionados com os significados de "humanidade" e "sensibilidade". Nesse sentido, Rawls (1997:38) fala do intuicionismo do "senso comum”. Voltaire se referia ao "senso comum” chamando-o de "razão grosseira”, "razão incipiente”, "primeira noção das coisas ordinárias”, “estado mediano entre a estupidez e o espírito. “Cet homme n’a pas le sens commun', est une grosse injure. 'Cet home a le sens commun', est une injure aussi; cela veut dire qu'il n'est pas tout à fait stupide, est qu'il manqué de ce qu'on appelle esprit. Mais d'où vient cette expression sens commun, se ce n'est des sens? Les hommes, quand ils inventèrent ce mot, faisaient l'aveu que rien n'entrait dans l'âme que par les sens; autrement, auraient-ils employé le mot de sens pour signifier le raisonnement commun? On dit quelquefois: 'Le sens commun est fort rare'; que signifie cette phrase? Que dans plusieurs hommes la raison commence est arrêtée dans ses progrès par quelques prejugés; que tel homme, que juge très sainement dans une affaire, se trompera toujours grossièrement dans une autre. (...) comment cet étrange renversement d'esprit peut-il s'opérer? Comment les idées, qui marchent d'un pas si régulier et si ferme dans la cervelle sur un grand nombre d'objets, peuvent-elles clocher si misérablement sur un autre mille fois plus palpable et plus aisé à comprendre? Cet homme a toujours en lui les memes principes d'intelligence; il faut donc qu'il y ait un organe vicié, comme il arrive qualquefois que le gourmet le plus fin peut avoir le goût dépravé sur une espèce particulière de nourriture.” (VOLTAIRE, 1994:477-479)
} 
como também o de que, em geral, os consensos se formam em cenários discursivos distorcidos, em que muitas vezes prevalecem exclusivamente as convicções morais de determinados indivíduos ou grupos mais fortes (política ou economicamente) em detrimento da generalidade dos outros interlocutores. Nem sempre a opinião pública tem razão em relação ao que é certo ou errado do ponto de vista moral (do que o Nazismo pode ser um exemplo eloquente).

Nos casos difíceis, em especial, nos quais as convicções morais não são auto-evidentes, dizer que o juiz moral ou o sujeito moral por excelência, abstraindo da realidade e se movendo do campo das ações humanas reais para o plano da inteligência, saberá construir o certo e o errado a partir das intuições morais prevalecentes nas tradições da comunidade em que se acha inserido, não parece uma resposta convincente ao problema do ceticismo moral, nem parece adequada para nos convencer acerca das possibilidades de cognitivismo moral em sentido amplo. Por outro lado, a resposta assim formulada pode significar a construção de um imperialismo moral sob o véu da ignorância de uma falsa moralidade racional consensual, como acontece com o senso comum em geral. Desse modo, tudo permanece no mais absoluto mistério. ${ }^{15}$

Hare (1979) desenvolve esse argumento tratando da questão da escravidão, em relação à qual suscita a interrogação: “O que há de errado com a escravidão?”. A conclusão central de Hare é a de que é perigoso sustentar que determinados juízos morais são auto-evidentes (ou, para alguns, óbvio), como Dworkin pretende dizer em relação a casos paradigmáticos que cita (genocídio, tortura de crianças etc). De nossa parte, pensamos que o problema dessa pretensão de que haja juízos morais auto-evidentes está precisamente no uso ideológico da construção teórica, uma vez que, ao se invocar uma suposta obviedade da natureza da moralidade ou de determinação ação humana (certa ou errada), fica evidente o propósito de afastar a possibilidade de um juízo crítico acerca dessa natureza e dos próprios sentidos ilocucionários e perlocucionários dos atos de fala moral, a fim de nos restringirmos apenas no sentido locucionário desses atos de fala. Há ainda um propósito subliminar de desqualificar o interlocutor, que, se não reconhece a auto-evidência da natureza dos atos de fala moral, não o faz, provavelmente, por alguma deficiência em termos de conhecimentos, de capacidade crítica ou mesmo porque estaria inserido num outro jogo de linguagem.

\footnotetext{
${ }^{15}$ Nesse sentido, a crítica de Alexy (1998:35): “L'argomento di gran lunga più forte è quello per cui dinanzi al fatto que uomini diversi percepiscono come evidenti verità differenti, l'intuizionismo non fornisce alcun criterio per distinguere le evidenze giuste dalle sbagliate, quelle genuine dalle false. Eppure Esso dovrebbe fornire próprio questi criteri, se volesse mantener fede Allá sua pretesa di fondare sul terreno della morale La possibilita di um sapere oggettivo o di una verità morale. In mancanza di un símile critério decisionale l'intuizionismo giunge allo stesso esito del soggettivismo ético. Per quanto siano fondate le obiezioni che l'intuizionismo muove contro il naturalismo, anche l'intuizionismo è tanto poço sostenibile quanto il naturalismo.” Do mesmo modo, Vázquez (2002:246-247): "Suponhamos que existem as propriedades não naturais do tipo das citadas - por exemplo, a propriedade de que algo constitui um dever - e se formulam dois juízos a respeito desta propriedade sobre a base de sua apreensão direta e imediata. Se duas pessoas (A e B), numa mesma situação, intuem respectivamente dois deveres que se contrapõem (A intui que ambas devem cumprir uma promessa feita anteriormente e B que não devem cumpri-la), qual das duas intuições é válida? Ambas, por acaso?.”
} 
Esse sentido ideológico (compreendendo a ideologia como falsa consciência) fica bem exposto quando se formulam indagações, no contexto da linguagem moral, tais como: "Você não considera que o genocídio é moralmente errado?”, "Você admite como moralmente certo o ato de tortura de crianças por puro prazer?”, "Você considera que a violação à dignidade da pessoa humana ou aos direitos humanos em geral pode ser qualificada como uma conduta moralmente aceita?", "Você não valoriza a vida humana?”. ${ }^{16}$

Por trás dessa pretensão de objetividade e verdade dos juízos morais situam-se pretensões políticas ou de uma linguagem de dominação, que bem revela o caráter aristocrático do intuicionismo moral, à medida que confere tal objetividade e verdade a consensos comunitários que não decorrem de situações comunicativas ideais (mesmo porque tais situações comunicativas ideais não existem) mas sim de imposições morais de uma elite qualificada que inculca nas tradições as suas próprias e peculiares visões de mundo, o que também se representa na invocação do "sujeito moral por excelência" ou do "homem moralmente educado". Em outras palavras, o que sustenta o intuicionismo moral é um projeto imperialista, no contexto do qual poderia aplicar-se o dito de Proudhon: "Quem diz humanidade quer enganar!”

A par do fundamento ideológico que norteia o intuicionismo moral, as dificuldades de se sustentarem como auto-evidentes, objetivos ou verdadeiros/falsos alguns juízos morais (considerando-se o falibilismo moral reconhecido por Dworkin) cumulam-se no fato de que a questão do certo/errado não diz respeito ao sentido locucionário dos atos de fala moral, mas sim nos seus sentidos ilocutório e perlocutório. O problema não está em sermos contra ou a favor o genocídio ou o terrorismo, mas sim em sabermos o que essas expressões significam e como o conhecer esse significado dos enunciados morais subjacentes nos motiva a pôr em prática determinada ação moral.

No caso específico da escravidão e da dignidade da pessoa humana é conhecida a diversidade dos seus sentidos ilocutórios ao longo da história. Basta reconhecer que, a despeito de fazermos filosofia moral desde que a humanidade existe, somente no final do Século XIX algumas culturas aboliram a restrição da liberdade segundo o que conhecemos por escravidão, pelo menos no plano da formalidade jurídica. ${ }^{17}$ Neste aspecto, a tese da resposta correta (que em Dworkin, ao contrário do que uma análise apressada poderia indicar, não significa "única resposta correta”, mas apenas e tão-somente a possibilidade de afirmar como certo ou errado determinado enunciado moral, ainda que em um contexto de conflitos) não supera as dificuldades propostas, notadamente porque não oferece caminhos epistemológicos para a compreensão dos sentidos ilocutórios e perlocutórios da linguagem moral, e para a superação das incertezas (uncertainty) desses sentidos.

\footnotetext{
${ }^{16}$ Para uma crítica aprofundada à ideologia dos direitos humanos e do abuso da invocação da dignidade da pessoa humana, v. Douzinas (2007 e 2009). Hare também atentou para esse aspecto ideológico do intuicionismo, ao mencionar o "widespread abuse of the appeal to human rights", que pode se transformar em uma "kind demagogy". (1979:103)

${ }^{17}$ Cumpre relembrar que no julgamento do conhecido caso Dred Scott v. Sandford (60 U.S. 393), de 1856, a Suprema Corte dos Estados considerou que a escravidão era compatível com a Constituição Federal, porque assegurava a propriedade dos senhores de escravos.
} 
Consideremos o exemplo do genocídio (que Dworkin invoca como caso paradigmático de auto-evidência moral por intuição). A Convention pour la prévention et la répression du crime de génocide das Nações Unidas (Artigo 6, 1948) define genocídio do seguinte modo: ${ }^{18}$

Dans la présente Convention, le génocide s'entend de l'un quelconque des actes ci-après, commis dans l'intention de détruire ou tout ou en partie, un groupe national, ethnique, racial ou religieux, comme tel:

a) Meurtre de membres du groupe;

b) Atteinte grave à l'intégrité physique ou mentale de membres du groupe;

c) Soumission intentionnelle du groupe à des conditions d'existence devant entraîner sa destruction physique totale ou partielle;

d) Mesures visant à entraver les naissances au sein du groupe;

e) Transfert forcé d'enfants du groupe à un autre groupe.

Partindo da análise dessa conceituação institucionalizada, percebe-se que a abrangência semântica da expressão "genocídio" alcança sentidos que estão muito fora dos nossos limites intuitivos normais, considerando à ideia básica de que o genocídio corresponde ao extermínio de membros de um grupo dotado de identidade cultural. São contra-intuitivos tanto a exigência da intenção (dolo) de destruir no todo ou em parte um grupo religioso, racial, ético ou nacional, como também a inserção no significado de genocídio hipóteses como atentados contra a integridade mental de membros do grupo, a adoção de medidas impeditivas de nascimentos no seio

${ }^{18}$ Definições semelhantes se encontram em outros textos normativos internacionais, como (1) o Estatuto de Roma do Tribunal Penal Internacional (Artigo 6: Aux fins du présent Statut, on entend par crime de génocide l'un quelconque des actes ci-après commis dans l'intention de détruire, en tout ou en partie, un groupe national, ethnique, racial ou religieux, comme tel: a) Meurtre de membres du groupe; b) Atteinte grave à l'intégrité physique ou mentale de membres du groupe; c) Soumission intentionnelle du groupe à des conditions d'existence devant entraîner sa destruction physique totale ou partielle; d) Mesures visant à entraver les naissances au sein du groupe; e) Transfert forcé d'enfants du groupe à un autre groupe.), (2) o Estatuto do Tribunal Penal para Rwanda (Artigo 2.2: 2. Le génocide s'entend de l'un quelconque des actes ci-après, commis dans l'intention de détruire, en tout ou en partie, un groupe national, ethnique, racial ou religieux, comme tel: a) Meurtre de membres du groupe; b) Atteinte grave à l'intégrité physique ou mentale de membres du groupe; c) Soumission intentionnelle du groupe à des conditions d'existence devant entraîner as destruction physique totale ou partielle; d) Mesures visant à entraver les naissances au sein du groupe; e) Transfert forcé d'enfants du groupe à un autre groupe.) e (3) o Estatuto do Tribunal Penal Internacional para a ex-Iugoslávia (Artigo 2: 2. Le génocide s'entend de l'un quelconque des actes ci-après, commis dans l'intention de détruire, en tout ou en partie, un groupe national, ethnique, racial ou religieux, comme tel: a) meurtre de membres du groupe; b) atteinte grave à l'intégrité physique ou mentale de membres du groupe; c) soumission intentionnelle du groupe à des conditions d'existence devant entraîner sa destruction physique totale ou partielle; d) mesures visant à entraver les naissances au sein du groupe; e) transfert forcé d’enfants du groupe à un autre groupe.). No Brasil, o genocídio é definido e punido na conformidade da Lei 2.889/1956, que assim o define: “Art. $1^{\circ}$ Quem, com a intenção de destruir, no todo ou em parte, grupo nacional, étnico, racial ou religioso, como tal: a) matar membros do grupo; b) causar lesão grave à integridade física ou mental de membros do grupo; c) submeter intencionalmente o grupo a condições de existência capazes de ocasionar-lhe a destruição física total ou parcial; d) adotar medidas destinadas a impedir os nascimentos no seio do grupo; e) efetuar a transferência forçada de crianças do grupo para outro grupo;”. 
do grupo, a submissão de grupos a condições existenciais capazes de ensejar a destruição física e a própria transferência forçada de crianças de um grupo para outro.

Dada essa diversidade de sentidos e o fato de que os conflitos morais envolvendo questões afetas ao genocídio possivelmente exsurjam no contexto das suas noções contra-intuitivas, perde a sua força a asserção de auto-evidência da natureza do enunciado moral "o genocídio é moralmente errado", uma vez que simplesmente fazer essa afirmação não nos auxilia diante de um sério conflito moral concreto em que é preciso, antes de mais nada, definir se se trata verdadeiramente de um caso de genocídio.

Outro aspecto que não poderia ser descurado é o de que alguns "genocídios" decorrem não da vontade deliberada de uma pessoa ou de um grupo em desfavor de outro, movidos apenas pelo desejo do extermínio do outro (um animus necandi em escala generalizada), mas a partir da ação violenta de grupos sociais rivais que vêem no extermínio do outro uma forma de auto-afirmação ética, racial, religiosa, cultural ou moral, ou como uma forma de sobrevivência diante das agressões sofridos pelo grupo oponente, como se especula ter ocorrido no caso das etnias hutus e tutsis em Ruanda. Sobre essas questões, as nossas intuições - sobretudo porque podem se revelar escassas a esse respeito — não podem ser aceitas como condições suficientes para um adequado juízo moral crítico-reflexivo sobre o problema moral posto e sobre quais ações humanas podem ser qualificadas como certas ou erradas do ponto de vista moral. Há algo além das intuições que deve ser dito, e há algo nas intuições que não é dito. ${ }^{19}$

\footnotetext{
${ }^{19}$ Uma passagem de Douzinas (2009:144) evidencia, adotando-se o exemplo do "genocídio”, como a linguagem moral pode ser ideológica: "É interessante comparar a disposição do Ocidente de bloquear e bombardear seus outrora aliados no Iraque com a reação ao genocídio de Ruanda. Durante alguns longos meses, em 1994, um milhão de pessoas foram chacinadas no que continua sendo, com o Camboja, o maior genocídio do século XX ou do 'século dos direitos humanos', depois do Holocausto. Segundo minutas de reuniões informais do Conselho de Segurança, posteriormente divulgadas, integrantes da força de paz das Nações Unidas enviaram mensagens detalhadas sobre o genocídio em progresso, no início de abril de 1994, e alertaram que a situação se agravaria rapidamente sem a presença dos oficiais da ONU. O general Dallaire, comandante da força de paz, enviou seis mensagens a Nova York, a primeiro logo em 11 de janeiro, alertando para a crise iminente e requerendo permissão para agir, mas recebeu uma resposta padrão do secretariado ordenando-lhe que não agisse. A prioridade número um dos Estados Unidos e da Grã-Bretanha foi retirar os integrantes da força de paz, pois quaisquer baixas provocariam um 'impacto negativo na opinião pública’. D acordo com a historiadora Linda Melvern, Karl Inderfurth, o representante norte-americano da ONU, declarou que a força de paz 'não era apropriada agora e jamais será' e que os Estados Unidos 'não tinham estômago para deixar qualquer coisa lá'. Tendo passado 80 por cento do tempo decidindo sobre a retirada dos integrantes da força de paz e apenas '20 por cento tentando obter um cessar-fogo', o Conselho finalmente votou, em 24 de abril, pela retirada, exceto por uma força simbólica de 270 homens. Cinco dias mais tarde, o presidente do Conselho propôs uma resolução declarando que um genocídio estava em curso e aplicando as sanções da Convenção do Genocídio. As potências ocidentais fizeram objeções; os representantes britânicos não queriam o emprego da palavra 'genocídio’ porque isso tornaria o Conselho um 'motivo de deboche'. As vidas de algumas centenas de integrantes das forças de paz ocidentais eram certamente mais importantes que as centenas de milhares de africanos. O general Quesnot, um militar francês que conhecia muito bem a situação ruandesa, estimou que '2.000 a 2.500 soldados 'determinados' teriam sido suficientes para conter a chacina'. Como retoricamente perguntou o embaixador nigeriano, 'a África saiu do mapa da questão moral?.”
} 


\section{A ÉTICA DOS DESAFIOS}

Há uma relação de continuidade entre o intuicionismo moral de Dworkin e a sua filosofia política. O liberalismo de Dworkin lida com a tensão entre justiça e ética (justiça e virtude), procurando traçar um equilíbrio conciliador entre as duas noções e com isso construir mitigações ao liberalismo político de base sócio-contratualista, focalizando especialmente a construção teórica de Rawls. Segundo Dworkin, o liberalismo político concentra-se no ideal da justiça, que se baseia na perspectiva da melhor distribuição agregada de bem-estar entre os membros de determinada comunidade. A noção de igualdade que norteia o liberalismo político é a de igualdade de bem-estar.

Desse modo, o liberalismo tensiona a ética representada nas formas de vida particulares a partir da base do princípio da justiça, que prega o bem-estar em sentido coletivo ou comunitário. As escolhas individuais dos membros da coletividade, no tocante ao modo como visualizam o conceito de vida boa, são aceitas somente quando passam pelo crivo da justiça vista como o conjunto dos impactos positivos que essas escolhas provocam no estado de coisas da comunidade. Há no liberalismo uma intrínseca noção de progresso que não pode ser contrariada pelos modos de vida particulares. Assim somente se pode pensar na ética justa, e ética justa é aquela que contribui para o progresso da coletividade pensado como o incremento de bem-estar social. O liberalismo político adota, portanto, o modelo que Dworkin denomina de modelo do impacto. Tal modelo ostenta as seguintes premissas fundamentais:

a) Não é possível sustentar um conceito de vida boa em si mesma, absoluto, porquanto a moralidade tem um sentido objetivo que se sobrepõe ao ethos dos indivíduos;

b) A noção de vida boa não se mede pelo sucesso pessoal, mas sim pelos impactos que as formas de vida particulares provocam no estado de coisas da comunidade, na felicidade da polis, de forma que o modelo é consequencialista e teleológico, uma vez que está preocupado com o produto final das ações humanas;

c) A moralidade (comunitária) se sobrepõe à ética (privada), vista aquela como o modo pelo qual lidamos com os outros e como definimos a "vida boa" em geral, ou seja, o modo pelo qual cuidamos de nós próprios e como definimos a "nossa" noção particular de vida boa. A ética somente tem sentido como instrumento para pensar e desenvolver a moralidade da vida boa coletiva. Nesse sentido, moralidade e justiça se associam como limitadores (e não como parâmetros) da ética individual, como mitigação das possibilidades e do conteúdo das escolhas individuais. Embora não impliquem a negação das virtudes do ético particular, a justiça confere-lhes um sentido restrito. Seu valor depende das implicações na objetividade do mundo;

d) Persegue-se o ideal substancialista do valor ético centrado nos valores culturais da comunidade, que não podem ser contrariados pelas formas de vida particulares, sob a crença de que a intuição social generaliza-se no sentido de que a ratio humana não pode descurar do sentido maior do bem-estar da comunidade; por decorrência o liberalismo parte da premissa substantiva da via boa coletiva, revelando um fundacionalismo moral desgarrado dos valores éticos. Um liberalismo sem ética consagra e propaga a separação entre justiça e virtude. E as virtudes éticas são julgadas sob as lentes da justiça comunitária e dos impactos que provocam neste contexto abrangente; 
e) O modelo do impacto converge para um elitismo e um progressivismo ético, haja vista que o ideal da justiça e do bem-estar são definidos a partir dos "melhores" parâmetros desenvolvidos a partir da antropologia metafísica do sujeito abstrato racional. "A vida boa" da coletividade é o que os sujeitos racionais e não os sujeitos individualizados e concretos definem. Neste cenário, reifica-se a ética, uma vez que passa a ser elemento do mundo objetivo que sofre os seus influxos. A ética somente tem valor em sentido objetivo;

f) Milita-se no campo da transcendência moral, negando-se à ética o status de valor indexado da moral nas particularidades das formas de vida singulares. A ética e a moralidade se confundem numa mesma objetividade; o indivíduo, ele próprio uma abstração, se valoriza como tal apenas enquanto partícipe da objetividade do mundo, da vida boa comunitária, da justiça do bem-estar social; esse transcendentalismo traduz-se também em relativismo axiológico, à medida que a justiça e a moralidade não são valores atemporais, mas são sim valores atrelados à cultura e às tradições de determinada comunidade. Dessa forma, o consequencialismo que sustenta o modelo do impacto não é um consequencialismo das regras, porquanto não advoga a ideia de que a construção da via boa seja apenas uma questão de princípios a serem aplicados; trata-se de um consequencialismo de atos, pelo que se avaliam os seus consectários na realidade cultural e existencial comunitária.

Não deixa de ser problemática a interpretação de Dworkin em relação ao conceito de bem-estar em Rawls, à medida que os seus dois princípios de justiça também contemplam regras acerca da distribuição de recursos básicos, sobretudo em favor dos menos favorecidos. Neste aspecto, a principal diferença entre o modelo ético do impacto e a teoria moral sustentada por Dworkin parece ser mesmo o intuicionismo moral que orienta o modelo ético dos desafios, o que é recusado pelo liberalismo de Rawls. Ao contrário de Rawls, Dworkin parece não concordar com a possibilidade do estabelecimento de prioridades entre valores em conflitos, deixando a solução para as intuições do sujeito moral.

Nesta perspectiva, Dworkin apresenta o modelo ético do desafio, de modo a enfrentar a tensão entre justiça e ética, entre justiça e virtude, entre moralidade e ética, entre comunidade e indivíduo, cujas principais premissas teóricas são as seguintes:

(1) No sentido de reservar ao indivíduo um espaço de liberdade protegido da moralidade coletiva tradicional, Dworkin defende que a noção de vida boa, fruto da escolha legítima do indivíduo, não pode ser avaliada segundo as suas consequências na realidade objetiva comunitária; vida boa consiste no exercício ou desempenho habilidoso de um projeto de vida particular visto como um desafio pessoal definido a partir dos recursos pessoais e impessoais básicos de que dispõe o indivíduo em determinadas circunstâncias corretas.

Desse modo, Dworkin procura afastar a ideia do modelo de impacto, segundo o qual não existiria um conceito de vida boa em si, independente da moralidade coletiva e da justiça comunitária. Ressalte-se que este “em si” em Dworkin não significa uma "ética material”, objetiva, realista, independentemente existente na realidade. Este “em si” tem o sentido da apropriação livre do indivíduo do seu poder de escolha dos seus projetos e desafios de vida pessoal, a sua liberdade de decidir que caminhos 
tomar a partir das contingências da realidade que se lhe apresenta e dos recursos que detém, não deixando de tomar em consideração os limites morais da comunidade apreendidos intuitivamente. Neste ponto, Dworkin fala de um "em si" ético como subjetividade contingente.

Fica evidenciada a base aristotélica da filosofia moral do modelo do desafio, segundo a qual "uma vida boa tem o valor inerente ao de um exercício realizado com destreza" e na qual a vida é considerada como o desafio humano mais global e abrangente, e são as nossas conquistas e progressos que revelam o quão bem sucedidos fomos na execução desse desafio. Sob esse enfoque, Dworkin inverte a lógica do modelo ético do impacto, sustentando que não é a moralidade que mede o valor da ética da vida boa particular, mas sim que a vida boa é um valor em si mesmo, porque é formal e porque constitui um método, um exercício e não propriamente a definição peremptória de uma ética substantiva qualquer. O liberalismo de Dworkin está aqui bem presente, sob a acepção da reserva de um espaço de intangibilidade absoluta da liberdade privada que se confunde com o espaço da ética privada, da liberdade de escolha de qualquer forma de vida que não seja antiliberal.

Neste círculo de privacidade ética, os influxos limitadores da moralidade coletiva não penetram precisamente porque, ao contrário da ênfase do modelo do impacto nas formas éticas substantivas, não há formas de vida substantivas pré-definidas segundo o modelo dos desafios. É o procedimento ou o método, uma espécie de devido processo legal em sentido substantivo, que resguarda a sobrevivência das formas de vida substantivas, que se desenvolvem livremente à margem das tradições culturais predominantes.

Distinguem-se a moralidade e a justiça, haja vista que enquanto a moralidade se apresenta como limite à ética, a justiça constitui-lhe apenas um parâmetro; enquanto entre moralidade e ética há, no modelo do impacto, uma hierarquia, no modelo do desafio há apenas uma tensão dialética, que se resolve não pela sobreposição do moral sobre o ético, mas pela preservação do ético que criticamente avalia a liberdade de submeter-se ao moral em nome da justiça. Neste contexto, há um espaço para o juízo crítico próprio da liberdade privada, que não se compagina com a imposição das intuições morais coletivas. A justiça assim se apresenta como um parâmetro brando ou maleável, respeitoso da ética privada.

(2) No modelo do desafio, o elitismo do modelo do impacto é substituído pelo pluralismo das formas de vida éticas particulares, que atuam livremente segundo os próprios parâmetros críticos da justiça. Aqui não há espaço para a sobreposição ou superação das éticas privadas pela cultura ou pela moralidade consensual da comunidade. Também o progressivismo moral coletivo do modelo do impacto é substituído pela neutralidade não abrangente em relação aos projetos individuais de vida boa, que não sofrem os influxos da moralidade coletiva. Neutralidade aqui tem o mesmo sentido adotado nas críticas de Dworkin ao ceticismo moral, porquanto significa "não tomar posição” em relação aos projetos individuais de vida boa.

Se por um lado, no campo da moralidade há uma marcante pretensão de progressivismo (moral), por outro, não se estabelece qualquer noção de progresso no campo da ética privada, a não ser o que exige a melhoria das formas de vida no 
tocante à distribuição dos recursos impessoais básicos, transferíveis pelo conceito de justiça distributiva de forma igualitária. Assim, o progresso se mede no campo da igualdade (da moralidade e da justiça), não no campo da liberdade ética particular. Neste, mantém-se uma posição de neutralidade que afasta qualquer valoração em termos de progresso ou retrocesso.

(3) O modelo do desafio não pretende superar o transcendentalismo moral universal, o que já se havia revelado na simpatia de Dworkin pelo construtivismo moral kantiano. Pretende sim indexá-lo à ética privada e às correlatas tradições e culturas da comunidade, num sentido positivo e construtivo. Para justificar essa indexação da transcendência moral comunitária aos projetos individuais de vida boa, Dworkin sustenta que há uma continuidade (e não uma descontinuidade, como prega o modelo do impacto) entre a ética e a moralidade, entre o mundo privado e a esfera pública, entre virtude e justiça, entre o indivíduo e sua comunidade. O sentido coletivo ou comunitário de vida boa constrói-se criticamente a partir das pluralidades de formas de vida ética particulares.

No modelo do impacto, há um descolamento entre o ideal coletivo de bem-estar e da moralidade pública, e os projetos éticos individuais, num processo que culmina via de regra na infra-hierarquização desses. No modelo do desafio, moralidade e eticidade são valores conexos, interligados e complementares, embora entre si registre-se uma constante tensão. Não há, portanto, uma oposição ou um distanciamento peremptório entre justiça, virtudes e comunidade. Os valores éticos são apreciados não porque integram a moralidade pública de uma comunidade cultural e política particular, mas sim porque revelam a singularidade de indivíduos livres e iguais em recursos básicos suficientes para definirem os seus próprios projetos de felicidade e vida boa, e realizá-los da forma mais habilidosa possível.

A principal intenção de Dworkin ao construir o modelo ético dos desafios é inserir fundamentos éticos no liberalismo político e construir um liberalismo mais igualitário. Sua pretensão é resgatar o indivíduo, em sua versão concreta, das garras da moralidade sufocante da visão comunitária do modelo do impacto, inserindo o conteúdo ético na moralidade. Cumpre destacar, antes de elencar as premissas do modelo moral-filosófico do desafio, que ambos os modelos estudados têm natureza formal, segundo destaca o próprio Dworkin.

Essa formalidade dos modelos (que, no caso do modelo do desafio, também poderia ser traduzida por procedimentalidade, sem qualquer prejuízo e até com certo ganho teórico e epistemológico) reside na circunstância de que neles não há um pré-compromisso com a ética. No modelo do impacto, pelo seu relativismo, esse pré-compromisso não existiria em razão do fato de o conceito de vida boa definir-se culturalmente, de forma transcendente e de acordo com as tradições que vigoram em determinada comunidade. No modelo do desafio, por sua vez, a formalidade moral se revela na premissa de que as formas de vida particulares têm atuação livre, nos limites da justiça comunitária, dos princípios liberais e da ética em terceira pessoa. Neste modelo, não há mitigação no campo da ética em primeira pessoa. Cada indivíduo é livre para escolher, numa sociedade justa em que haja igualdade de distribuição de recursos impessoais e básicos, aquilo que considera a melhor forma 
de vida, o seu próprio sentido crítico de felicidade e vida boa.

Os modelos diferem também quanto ao grau de substancialidade ética, que é mais denso e menos radical no modelo do desafio dworkiniano, à medida que este aceita todas as formas de vida que não contrariem os princípios liberais fundamentais e ao ideal da justiça, ora vista não como distribuição de bem-estar social, mas como distribuição equitativa ou igualitária de recursos básicos que permitem ao indivíduo livre no seu campo ético desenvolver a sua escolhida forma de vida singular. Ao contrário, no modelo do impacto, restringem-se todas as formas de vida em face das consequências que essas provocam no estado objetivo da cultura e das tradições da comunidade. Reconhece-se então uma prioridade comunitária.

Dworkin faz uma distinção peculiar entre ética e moralidade, conceituando esta como uma modalidade do juízo ético voltado para o modo como devemos tratar os outros, ao passo que a ética propriamente dita diria respeito aos juízos que desenvolvemos no âmbito da liberdade e da proporção de uma vida boa para nós próprios. ${ }^{20}$ Desse modo, a moralidade se ligaria aos conceitos universais da ética e se inseriria no contexto da comunidade e do juízo da igualdade entre os homens.

Moralidade associa-se ao intersubjetivo comunitário arraigado na ideia da justiça universal. A ética em sentido estrito revelaria os projetos individuais, como exercício da liberdade do homem isolado e autônomo em relação às suas comunidades. Moralidade é um exercício de política inserida na esfera pública. Ética é um exercício de autonomia particular no contexto da esfera privada do indivíduo, que está preocupado em desenvolver os seus projetos associados aos desafios por ele definidos.

Segundo Dworkin, moralidade e eticidade revelam-se conceitos interdependentes e complementares, pois nem há moralidade sem ética, à medida que para que a justiça e a comunidade se desenvolvam é preciso não suprimir mas apenas subordinar as formas de vida particulares e seus projetos individuais em nome dos projetos coletivos da comunidade, além de ser necessários fornecer-lhes os recursos necessários para tanto, nem ética sem moralidade, pois os projetos individuais não podem se concretizar numa comunidade injusta e desigual. Somente numa sociedade em que se viva a igualdade na distribuição dos recursos básicos é possível que a liberdade privada possa produzir os frutos necessários ao crescimento, ao progresso e ao sucesso do indivíduo. Assim se entende porque a igualdade é uma virtude soberana.

Neste aspecto, a filosofia moral de Dworkin inverte a tradicional distinção entre a ética como juízo ligado aos valores universais, e a moralidade como formas de vida ou conteúdos morais individualizados. O particular da moral se universaliza, e o universal da ética se particulariza. Nos dois campos (moral e ética), contudo, evidencia-se uma teleologia comum, assentada no sentido metodológico mas diversa no conteúdo. Na ética, essa teleologia se traduz na noção de bem-estar individual, que se não vai confundir com o benestarismo das doutrinas contratualistas tradicionais (Rawls), porque

${ }^{20}$ Nem sempre Dworkin parece permanecer fiel a essa distinção, como se verifica quando ele fala do “entorno ético" próprio da comunidade, que influencia os tipos de vida que podem levar os seus membros, dando a entender que "ética”, neste sentido, se refere às convicções morais coletivas e não aos projetos individuais de vida (DWORKIN, 1996:139). 
desenvolve o conceito de distribuição de recursos básicos (ou uma distribuição de meios) em vez do conceito de distribuição de felicidade como resultado (uma distribuição de fins).

No campo da moralidade, destaca-se uma teleologia de justiça intersubjetiva. Não estaria Dworkin falando, em ambos os casos, de bem-estar, ainda que na forma peculiar da distribuição de recursos? O que significa "tratar bem os outros”? Tratar bem os outros não seria meditar sobre o melhor modo de distribuição de recursos a fim de satisfazer a noção de igualdade, de tal maneira que essa distribuição de recursos seria o ponto de encontro entre moralidade e ética, entre o universal e o particular, entre justiça e virtude, entre o correto e o bom? E, partindo da ideia de que seja verdadeira essa premissa, não se correria o risco da hierarquização em grau inferior das virtudes pessoais em relação ao princípio da justiça? Ainda não se incorreria no risco de afirmar que a igualdade tem um peso e uma importância superior em relação à liberdade individual, de modo que Dworkin seria mais amigo dos comunitaristas do que dos liberais? Como falar em liberalismo e tolerância liberal num cenário em que o indivíduo está subordinado a sua comunidade?

Tais questões convergem para a concepção aristotélica da ética como o "estudo do viver bem”, seja no plano individual, seja na esfera comunitária ou política. Neste cenário, interligam-se o político e o filosófico, à medida que a ponderação e o equilíbrio entre as diversas visões particulares do mundo e dos projetos ou desafios postos ou definidos pelos indivíduos, como bem retratada no estudo sobre os limites da tolerância liberal, depende primordialmente da forma como construímos filosófica, crítica e prudencialmente as nossas visões gerais sobre a vida boa e sobre justiça. A ética apresenta-se como fundamento ou motivação do liberalismo.

Mas por que o liberalismo procura sublimar os juízos éticos que se vinculam à noção de vida boa para nós mesmos por ocasião do debate de grandes questões políticas, como nos casos das células-tronco, da delimitação de terras indígenas, do abortamento de fetos anencefálicos etc? Como conciliar a ideia de que a ética é um fundamento do liberalismo se, por vezes, nos hard cases ou nos dilemas morais há um curto-circuito entre o pensamento liberal e as virtudes do juízo ético cotidiano? O que fazer com esse conflito entre liberalismo e ética?

Segundo Dworkin há duas estratégias para enfrentar esses problemas. A primeira é a denominada tese da descontinuidade, que bem se revela no procedimentalismo das doutrinas sóciocontratualistas, as quais desenvolvem um conceito artificial do político que permitiria a não sublimação dos juízos éticos particulares dos indivíduos integrantes de uma determinada comunidade. O descontínuo do ético estaria na artificialidade e na neutralidade do político. O político forneceria apenas o espaço discursivo necessário para que o ético se revelasse, vedado qualquer compromisso com formas concretas de vida boa ou, no sentido que estudamos, vedada qualquer tomada de posição acerca das formas de vida ética. Nessa percepção, contudo, institui-se um paradoxo, que se revela na circunstância de que a ética, pensada dworkinianamente como formas particulares da vida boa e vista como fundamento do liberalismo político, perde a sua função fundante se o juízo político-liberal não pode com ela estabelecer laços substantivos mais profundos. A descontinuidade entre o ético e o político cai num particularismo de base não fundacionista.

DIREITOS FUNDAMENTAIS E E JUSTIÇA N' 12 - JUL./SET. 2010 
A segunda estratégia, defendida por Dworkin, é a da continuidade. Na construção dessa continuidade apresenta-se como base a ideia de que o político e o ético estão interligados e se complementam, porque no debate das grandes questões políticas devem estar disponíveis as mais diversas visões particulares do mundo e da noção de vida boa. Não há aqui um pedido liberal de esquecimento das virtudes e dos projetos individuais. Todos entram na cena do debate político. Dworkin, contudo, opera uma redução estratégica, para dizer que somente prevalecem os juízos éticos que sejam os mais gerais e abrangentes, o que não deixa de ser uma sublimação seletiva de formas de vida ética particulares.

Permanece em aberto, contudo, a questão sobre como o particular sobrevive diante do comunitário que se funda sobre um conceito abstrato. A questão é saber como sobrevivem as liberdades individuais santificadas pela doutrina liberal diante de uma perspectiva de vida boa comunitária que se constrói metafisicamente, segundo uma contrafactual e intuitiva confiança na cognição do bem ou do justo pela abstração da maioria racional cognoscente ou de um sujeito moral por excelência.

Se o conceito da vida boa se desenvolve segundo o que pensa intuitivamente uma maioria racional ou um habitante do reino dos fins morais, persiste o problema da rejeição liberal das éticas privadas. Também sobra pouco do substancialismo ético prometido por Dworkin, diante da contrafactual possibilidade de que a percepção intuitiva da maioria racional dos comunitários, em verdade, seja a mera superposição da intuição ética de parcela da comunidade acerca do conceito de vida boa, especialmente aquela que detém maior poder de influência nos processos políticos decisórios do conceito de vida boa comunitária, de forma que a ideologia intuicionista no campo moral, como vimos, também mostraria as suas garras no campo político.

Sob essas premissas, seria possível, em princípio, admitir que o liberalismo igualitário de Dworkin ainda não é um liberalismo radical, porque não hipostasia a potência e a singularidade das formas de vida éticas particulares. O seu conceito de igualdade avança o aristocrático e o elitista da filosofia moral do modelo do impacto, tal qual o conceito consequencialista aristotélico, não conseguindo superar a abstração do sujeito ética racional no plano da inteligência, ainda que construída à luz da metáfora da maioria guardiã da racionalidade do bem viver para todos, cuja efígie é o juiz Hércules, no campo jurídico, e o sujeito moral por excelência, no campo da teoria moral.

Este ponto merece destaque: o intuicionismo de Dworkin necessita (assim como o deontologismo de Kant) de um sujeito moral por excelência, o habitante do reino dos fins (mundo da inteligência), o "superego da nossa sociedade órfã" (Ingeborg Maus). ${ }^{21}$ Se, por um lado, imaginou-se que esse sujeito moral poderia estar dentro de cada um de nós, em nossas consciências morais, ou mesmo que poderia ser representado pela comunidade moral antropomorfizada, o projeto político da filosofia moral de Dworkin contraria essas suposições, uma vez que, nas sociedades modernas, o sujeito moral por excelência para Dworkin não é nem o indivíduo (ainda que concebido como "pessoa" abstrata ou metafísica), nem a comunidade política em que ele se acha inserido, mas sim a figura dos juízes.

${ }^{21}$ Sobre a natureza deontológica/teleológica do intuicionismo, v. Rawls (1997:43-44) e McNaughton (2000:269). 
Para Dworkin (2004), as sociedades modernas elegeram os juízes como seu superego, sobretudo nas décadas que sucederam a Segunda Guerra Mundial, e conferiram-lhes status e poder suficiente para analisar e decidir, ainda que com base em suas convicções (ou intuições) pessoais (o que para Dworkin é um fato inevitável no contexto da judicial adjudication), as mais diversas e as mais controvertidas questões de moralidade política enfrentadas, seja no campo administrativo, seja no cenário das matérias constitucionais, o que envolve conflitos morais como os correlatos aos temas do aborto, da eutanásia, da discriminação racial, da proteção das minorias etc.

Desse modo, embora os juízes também decidam sobre questões de ética individual (como seria para o autor a questão do aborto), os dilemas morais que lhes são submetidos tratam muito mais de questões de moralidade política, o que lhes assegura o status de sujeitos morais da comunidade. Desse modo, a filosofia moral dos juízes é sobretudo uma forma de política. Neste contexto, Dworkin (2004: 73) fala de uma "secular judicial papacy", para identificar esse fenômeno de expansionismo político dos juízes (ou sua transformação social em papas seculares), segundo o que se convencionou denominar de judicialização da política, que, para o autor, vem fundamentado num idêntico expansionismo moral dos juízes legitimado socialmente,

So there is no bedrock of interpersonal consensus or institutional allocation of power or historical fact on which a constitutional judge can rely in place of expressing his or her own personal convictions of political morality. Every decision that a judge makes to enforce the broad moral provisions of a constitution to new issues demands the exercise of the judge's own judgment of substantive justice or the judge's own understanding of what a fair distribution of political power requires.

Desse modo, ao criticar a ideia da neutralidade moral dos céticos, Dworkin também está a rejeitar a possibilidade de uma neutralidade moral dos juízes no contexto da judicial adjudication. Por mais que se invoque a ideia do direito como integridade, especialmente no campo das referências jurisprudenciais dos demais juízes (ou da comunidade dos juízes e tribunais), não haveria como evitar a conclusão de que o juiz decide com base em suas próprias convicções morais substantivas e não haveria nenhum outro critério para avaliar a correção moral dessas convicções além das próprias intuições. ${ }^{22}$ Neste aspecto, além de um intuicionismo moral hispotasiado, tem-se em Dworkin notadamente uma profissão de fé nos juízes como sujeitos morais por excelência, por intermédio dos quais valeria a pena correr os riscos em termos de legitimidade política. Essa profissão de fé na integridade nos juízes como

\footnotetext{
${ }^{22}$ Neste ponto, destaca-se a crítica de Waluchow (2007:67): “Hay dificultades en la opción de indización que se aplican específicamente a la teoría de la integridad de DWORKIN y su visión del derecho como una red inconsútil de prerrogativas morales. Si el derecho debe ser indizado en relación con los tribunales, no es fácil advertir cómo puede ser concebido como un esquema unificado de derechos (y responsabilidades) reconocidos en la interpretación constructiva del sistema jurídico de Hércules, un esquema que ha de ser aplicado consistente e igualmente, en el espíritu de integridad y fraternidad de todos los ciudadanos en todos los contextos. Esto es así porque Hércules es sólo un juez en un tribunal. El derecho será diferente para otros jueces en otros tribunales y los litigantes tendrán derechos jurídicos diferentes a diferentes decisiones por parte de aquéllos.”
} 
superego moral das sociedades modernas conduz Dworkin (2004:78) a considerar o judicial papacy como um modelo mais adequado politicamente do que outros modelos teóricos de uma democracia fundada no pluralismo ético e no multiculturalismo moral,

Government by adjudication is newly appealing for a different reason as well: It seems as well: It seems better suited than the alternatives to the cultural and ethical pluralism that is so marked in modern political communities and associations. Adjudication is constructivist rather than oracular: Though judges rely, as I have been insisting, on their own personal moral convictions, they accept an institutional responsibility for integrity with what other judges have done and will do, which means that the body of principle that they together construct by way of constitutional interpretation is more likely to be abstract and less tied to any particular cultural tradition. And the political rather than ethical character of these principles contributes markedly to that result.

A despeito da sinceridade acadêmica exposta neste trecho, é impossível não se ver tomado de desconfianças em relação à proposta de uma subjetivação hispostasiada do processo político como a apresentada por Dworkin, sobretudo se considerarmos possível a ideia de que o expansionismo político dos juízes, embora sendo um fato, constitui um fenômeno sociológico contingente e marcado pelo momento histórico em que vivemos, no contexto político do qual há uma rediscussão do papel das autoridades tradicionais em benefício dos juízes. Desse modo, sendo um fato temporário e mesmo não abrangente, se considerada a realidade política global, em que diversos outros atores políticos estatais e não estatais tem assumido papéis de protagonismo político, não há por que hispotasiar o paternalismo moral dos juízes, razão por que um liberalismo igualitário deve ser substituído por um liberalismo mais radical, que eleve o indivíduo em relação à sua comunidade moral.

Esse paternalismo moral produz esse paradoxo da "perspectiva pessoal da maioria”, que esvazia de sentido a distinção entre as duas estratégias de enfrentamento do problema do conflito entre ética e liberalismo, uma vez que se identifica uma continuidade (motivacionalidade) entre o particular e o comunitário, entre a ética e o político, entre virtude e justiça, entre os projetos pessoais de vida boa e os projetos racionalmente determinados pela maioria dos comunitários como sendo o conceito geral de vida boa.

Da mesma forma como no contexto do sóciocontratualismo há um descompasso entre os projetos pessoais do indivíduo e a noção geral do bem-estar, à medida que o bem-estar social não seria a soma dos projetos individuais de vida boa. Também há um descompasso entre o que a maioria racional define como vida boa e o que os sujeitos concretos e individualizados elegem como projetos pessoais de bem-estar. Aqui se confundem descontinuidade e continuidade igualitária para se justificar o esquecimento da liberdade privada. Desse modo, não se constrói nem uma sociedade igualitária nem uma sociedade livre. Entre liberais e comunitários, a balança de Dworkin, como tudo indica, parece pesar mais, ainda que involuntariamente, para o lado destes.

Esta tendência se confirma quando Dworkin sustenta que definimos os nossos projetos éticos de vida boa particular a partir de uma intuição do que avaliamos como a moralidade da distribuição equitativa de recursos. Neste aspecto, que contradiz a 
estratégia da continuidade, Dworkin conclui que a moralidade dá forma à ética. É a noção intuitiva da vida boa coletiva que modela os nossos projetos pessoais de vida boa. Mas, neste caso, teríamos um alto preço a pagar, o custo da própria autonomia privada, que parece sucumbir nessa prática indistinção entre subjetividade e intersubjetividade comunitária.

Dworkin sustenta que valores morais comunitários devem prevalecer sobre os projetos éticos individuais, a partir da perspectiva de uma integração política dos indivíduos em relação aos projetos de vida boa da sua comunidade. Parte-se da ideia de que nenhum indivíduo com espírito crítico se sentiria satisfeito eticamente, após a definição de seus desafios éticos pessoais, se estivesse inserido numa comunidade profundamente injusta, na qual se desenvolvesse uma profunda desigualdade de distribuição de recursos e bem-estar. Desse modo, não se poderia cogitar da vida boa individual num cenário de “imoralidade” política comunal.

Por conseguinte, os projetos éticos devem, antes de tudo, desenvolver o conceito de vida boa em sentido coletivo, o que inclui a necessidade de o indivíduo atuar com vistas ao aperfeiçoamento das instituições comunitárias (aí incluindo o Legislativo, o Governo, o Judiciário, os sindicatos, associações em gerais, clubes e todas as formas de coletividade). Assim, a definição de seus projetos de vida (ética) sofrem certa influência do quadro política comunitário e é necessário que o indivíduo se identifique portanto com a sua comunidade para que possa eticamente definir e dar prosseguimento aos seus projetos individuais, notadamente porque a escolha das formas de vida individuais dependem, mais destacadamente, da igualdade na distribuição impessoal de recursos básicos, o que não seria implementado de forma ética, por exemplo, se as instituições comunitárias e a própria comunidade não estiveram suficientemente desenvolvidas e aperfeiçoadas, seja pela corrupção moral, seja pela despreocupação e intolerância com os projetos éticos. "Los ciudadanos se identifican con su comunidad política cuando reconocen que esta posee una vida comunal, y que el éxito o fracaso de sus propias vidas depende éticamente del éxito o fracaso de dicha vida comunal."23

Se os valores morais da comunidade devem prevalecer sobre os projetos éticos, pode-se dizer que fica afastado a neutralidade que o liberalismo exige das instituições comunitárias ou do próprio Estado? Dworkin propõe que essa dificuldade poderia ser superada assegurando a essas instituições apenas as deliberações políticas de natureza formal, como a própria definição do modo de distribuição dos recursos básicos com os quais os indivíduos poderiam escolher e implementar as suas escolhas pessoais. Assim, a necessária neutralidade estatal em relação aos projetos éticos estaria assegurada, ao mesmo tempo em que se asseguraria a tolerância liberal.

É interessante notar que à rejeição de Dworkin à neutralidade no campo da filosofia

\footnotetext{
${ }^{23}$ Dworkin, 1996:176. Em outra passagem (1996: 178-179): “El liberal integrado no separará su vida privada de su vida pública de esta manera. Considerará que su vida habrá desmejorado — será una vida menos buena de la que hubiera podido tener — si vive en una comunidad injusta, sin importar qué tanto haya trabajado para hacerla justa. Considero que esta fusión de moral política e interés crítico individual constituye el verdadero núcleo del republicanismo cívico, la importante manera como los ciudadanos deberían unir sus intereses y su personalidad a la comunidad política. Dicha fusión afirma una idea claramente liberal, que florece únicamente en una sociedad liberal.”
} 
moral - com a qual se rejeitam as propostas do ceticismo moral e se assegura o descritivismo moral - não está associada uma igual recusa da neutralidade no campo da filosofia política (liberal). Muito ao contrário, a rejeição da neutralidade filosófica serve precisamente para fundamentar a defesa da neutralidade e a tolerância política. Assim se conclui porque o objetivo de Dworkin ao refutar os arquimedianos que se apóiam na ideia da neutralidade para justificar o ceticismo moral é principalmente o de se contrapor à ideia de que não é possível constatar o certo e o errado em questões morais, o que é próprio do seu intuicionismo moral, como vimos.

Se, segundo Dworkin, é possível e até mesmo intuitivo reconhecer como moralmente erradas determinadas condutas, as contraposições ou as interferências nessas condutas não podem ser admitidas senão como moralmente justificadas, e vice versa. Assim, a neutralidade moral constitui ela própria uma moralidade substantiva, que pode ser definida como certa ou errada. Tais conclusões têm reflexos no campo político, especialmente no que diz respeito à atuação do Estado ou da comunidade. Se a neutralidade moral pudesse justificar um ceticismo em questões de valores morais não se poderia afirmar como certa ou errada a interferência paternalista do Estado ou da comunidade política na liberdade individual e nos projetos pessoais de vida boa (como no caso dos homossexuais, por exemplo).

Somente a partir da rejeição do ceticismo em questões morais (e da correlata neutralidade que a sustenta, segundo alguns arquimedianos) é possível exigir do Estado a necessária tolerância e neutralidade política em relação às escolhas individuais concernentes aos projetos particulares de vida boa. Por isso, "si la vida de una comunidad se limita a las decisiones políticas formales, y si por lo tanto sus logros críticos dependen únicamente del éxito o fracaso de sus decisiones legislativas, ejecutivas y adjudicativas, entonces podemos aceptar la primacía ética de la vida de la comunidad sin abandonar ni comprometer la tolerancia y neutralidad liberal con respecto a la buena vida. Simplemente repetimos que el éxito en las decisiones políticas exige tolerancia.”24

Os problemas dessa proposta não são tão diversos daqueles enfrentados pelas éticas de base aristotélica, dentre os quais se destaca o de ser uma filosofia moral demasiadamente exigente e perfeccionista (moralmente progressivista), à medida que reclama dos indivíduos o sacrifício de seus projetos individuais em nome, primeiramente, do bem-estar coletivo. Assim, o modelo ético dos desafios parece também ser sacrificado em nome do modelo dos impactos positivos que esse sacrifício pode causar no bem-estar geral da comunidade, numa espécie de sacrifício geral do indivíduo pelo cidadão, uma transformação geral do indivíduo em funcionário público em exercício permanente.

Também é uma teoria moral exigente no sentido de que os interesses volitivos (bem-estar volitivo) dos indivíduos (o que os indivíduos querem para si) devem subordinar-se aos interesses críticos (bem-estar crítico) dos cidadãos (o que esses devem querer para si, considerando a realidade social, política e moral de sua comunidade).

\footnotetext{
${ }^{24}$ Dworkin, 1996:177. No mesmo sentido das conclusões, Kymlicka (2006:257): “Os liberais, porém, não endossam o ceticismo. Uma razão é que o ceticismo, de fato, não apóia a autodeterminação. Se as pessoas não podem cometer erros nas suas escolhas, os governos tampouco podem. Se todas as maneiras de vida são igualmente valiosas, então, ninguém pode reclamar quando o governo escolha um modo de vida específico para a comunidade. Portanto, o ceticismo deixa a questão por solucionar.”
} 
Novamente a abstração metafísica da pessoa sublima o indivíduo real, de carne e osso, num projeto político de base liberal que pretende a prevalência comunitária, descurando novamente das bases ideológicas que tal prevalência carrega consigo.

O indivíduo real, neste contexto, já não deveria perguntar sobre os seus interesses e escolhas pessoais, mas sim sobre os interesses racionais e objetivos (críticos) que um indivíduo abstrato deveria perseguir no seu caso. Trata-se de uma tarefa ingrata senão impossível, de pretender uma reconciliação liberal entre um perfeccionismo moral comunitário e uma contraditória autodeterminação do indivíduo. É nesse cenário de dificuldades que a ética cede o seu lugar para a política, confirmando a histórica tensão entre justiça e virtude.

\section{CONCLUSÕES}

Na perspectiva de fundamentar eticamente o seu liberalismo, Dworkin desenvolve uma filosofia moral estratégica para a sua filosofia política. O seu intuicionismo moral - que se consagra na ideia de que os juízos morais podem ser qualificados como certos ou errados com base em uma capacidade reflexiva deferida aos sujeitos moralmente educados - serve para justificar o fato de não haver respostas metodológicas racionais para o estabelecimento de uma escala de prioridades de convicções morais, princípios, políticas e regras jurídicas.

Neste contexto, os conflitos morais são resolvidos estritamente com base nas intuições que poderiam fazer parte do senso comum de uma comunidade moral dotada de capacidade de ponderação, à míngua de uma epistemologia das prioridades. O pluralismo moral que justifica o intuicionismo e a falta de respostas no campo epistemológico dos juízos de ponderação de conflitos morais é o mesmo que justificará a seleção de um sujeito moral por excelência, capaz de identificar as intuições morais comunitárias, qualificar os projetos éticos dos indivíduos e dar conteúdo à moralidade.

A crítica intuicionista ao ceticismo no campo das convicções, valores e juízos morais tem o propósito político de sustentar a tolerância e a neutralidade das instituições comunitárias e estatais. Acreditar na objetividade e na verdade dos juízos morais significa, antes de tudo, consagrar a tese liberal da autodeterminação dos indivíduos, embora essa autodeterminação não pareça ofertar maior resistência diante da antropomorfização da comunidade e da seleção social de um sujeito moral capaz de dirimir os conflitos de intuições individuais em torno dos projetos éticos.

Neste aspecto, a recusa a um paternalismo estatal generalizado é substituído por um paternalismo subjetivo ainda institucionalizado na figura dos juízes. Consequentemente, o pluralismo e o multiculturalismo que justificaram a adoção de um intuicionismo ético perdem agora o seu sentido e são substituídos por uma profissão de fé na integridade do sujeito moral eleito socialmente, na esperança de que essa integridade moral não se converterá num emotivismo ético irracional.

\section{REFERÊNCIAS BIBLIOGRÁFICAS}

ALEXY, Robert. Teoria dell'argomentazione giuridica. La teoria del discorso razionale come teoria della motivazione giuridica. Traduzione di Massimo La Torre [Theorie der juristichen Argumentation. Die Theorie des rationalen Diskurses als Theorie der juristichen Begrundung, 1978]. Milano: 1998.

DIREITOS FundAMENTAIS E E JUSTIÇA N' 12 - JUL./SET. 2010 
CANTO-SPERBER, Monique. A Inquietude moral e a vida humana. Tradução de Nicolás Nyimi Campanário [L’inquiétude morale et la vie humaine, 2001]. São Paulo: Loyola, 2005.

DANCY, Jonathan. Intuitionism. In: SINGER, Peter (ed.). A companion to ethics. London: Blackwell, 1993.

DOUZINAS, Costas. Human rights and empire. The political philosophy of cosmopolitanism. New York: Routledge-Cavendish, 2008.

DOUZINAS, Costas. O Fim dos direitos humanos. Trad. de Luzia Araújo [The end of human rights, 2002]. São Leopoldo: Unisinos, 2009.

DWORKIN, Ronald. Ética privada e igualitarismo politico. Traducción de Antoni Domènech [Foundations of liberal equality, 1990]. Barcelona: Paidós, 1993.

La Comunidad liberal. Traducción de Claudia Montilla [Liberal community, 1989]. Santafé de Bogotá: Siglo del Hombre, 1996.

Objectivity and truth: you'd better believe it. Philosophy and public affairs, vol. 25, n. 2, 1996, p. 87-139.

The Secular papacy. In: BADINTER, Robert; BREYER, Stephen (ed.). Judges in contemporary democracy. An international conversation. New York: New York University, 2004.

FUKUYAMA, Francis. Nosso futuro pós-humano. Trad. Maria Luíza X. de A. Borges [Our poshuman future, 2002]. Rio de Janeiro: Rocco, 2003.

HARE, Richard M. Ética: problemas e propostas. Trad. de Mário Mascherpe e Cleide Antônio Rapucci [Sorting out ethics, 1997]. São Paulo: Unesp, 2003.

Moral conflicts. The tanner lectures on human rights. Disponível em http://www.utilitarian.net/singer/by/tanner.pdf. Acesso em 30 jul. 2010.

What is wrong with slavery? Philosophy and public affairs, vol. 8, n. 2, 1979, p. 103-121.

KYMLICKA, Will. Filosofia política contemporânea. Uma introdução. Tradução de Luís Carlos Borges [Contemporary political philosophy - An introduction, 2006]. São Paulo: Martins Fontes, 2006.

McNAUGHTON, David. Intuitionism. In: LAFOLLETTE, Hugh. The Blackwell guide to ethical theory. London: Blackwell, 2000.

NERI, Demetrio. Filosofia moral. Manual introdutivo. Tradução de Orlando Soares Moreira [Filosofia morale. Manuale introdutivo, 1999]. São Paulo: Loyola, 2004.

PIGDEN, Charles R. Naturalism. In: SINGER, Peter (ed.). A companion to ethics. London: Blackwell, 1993.

RAWLS, John. História da filosofia moral. Trad. de Ana Aguiar Cotrim [Lectures on the theory of moral philosophy, 2000]. São Paulo: Martins Fontes, 2005.

Uma teoria da justiça. Trad. de Almiro Pisetta e Lenita M. R. Esteves [A theory of justice, 1971]. São Paulo: Martins Fontes, 1997.

SCHMITT, Carl. La tirannia dei valori. Milano: Adelphi, 2009.

VÁZQUEZ, Adolfo Sánchez. Ética. Trad. de João Dell’Anna [Ética, 1997]. Rio de Janeiro: Civilização Brasileira, 2002.

VOLTAIRE. Dictionnaire philosophique. Paris: Gallimard, 1994.

WALUCHOW, Wilfrid J. Positivismo jurídico incluyente. Traducción de Marcela S. Gil y Romina Tesone [Inclusive legal positivism, 1994]. Madrid: Marcial Pons, 2007. 